\title{
Spatial and Temporal Patterns of In Situ Sea Surface Temperatures within the Gulf of Mexico from 1901-2010
}

\author{
Jason Allard', John V. Clarke III', Barry D. Keim² \\ ${ }^{1}$ Department of Physics, Astronomy \& Geosciences, Valdosta State University, Valdosta, GA, USA \\ ${ }^{2}$ Department of Geography and Anthropology, Louisiana State University, Baton Rouge, LA, USA \\ Email: jmallard@valdosta.edu
}

Received 10 May 2016; accepted 12 August 2016; published 15 August 2016

Copyright (C) 2016 by authors and Scientific Research Publishing Inc.

This work is licensed under the Creative Commons Attribution International License (CC BY). http://creativecommons.org/licenses/by/4.0/

(c) (7) Open Access

\section{Abstract}

This work examines the spatial and temporal patterns of seasonal sea surface temperatures (SSTs) across the Gulf of Mexico (GoM) for the period 1901-2010. The Extended Reconstructed Sea Surface Temperature, version 4 (ERSST.v4), dataset was selected for this study over other reconstructions because of its $2^{\circ} \times 2^{\circ}$ grid cell spatial resolution, its recent update to adjust for known biases in SST observations, and its ability to be compared to other in situ studies of GoM SSTs. The monthly ERSST.v4 data were averaged seasonally for each year and grid cell in the GoM. Seasonal SST trends were then calculated for each grid cell with varying start dates (e.g., 1901-2010, 19112010) to account for nonlinear SST changes over the study period. Results indicate that the GoM SSTs closely resemble those of global annual temperature trends: SSTs warmed from 1901 to 1940, followed by a period with little trend or a slight cooling until the mid-1970s, and then a warming afterwards through 2010. The spatial patterns and magnitudes of SST changes, however, varied by season and location within the GoM. The spatial patterns involved gradients with latitudinal and/or longitudinal components: a southwest-northeast (warmer-cooler) gradient in winter, an east-west (warmer-cooler) gradient in spring and fall, and a northwest-southeast (warmercooler) gradient in summer. The magnitude of SST changes tended to be largest in summer, followed by spring, fall, and winter. The long-term (1901-2010) SST trends were significant throughout the GoM in summer and fall, but only significant towards the southwestern GoM in winter and spring. These results have implications in discussion of climate change and its impacts on tropical activity in the GoM Basin.

\section{Keywords}

Sea Surface Temperature, Gulf of Mexico, Temperature Reconstructions, Temperature Variability 


\section{Introduction}

The oceans' extensive total water volume, large thermal capacity, and ability to transfer and exchange heat by currents and mixing play a dominant role over the atmosphere, land, and cryosphere [1]-[4]. Approximately 90\% of the excess heat energy added to Earth's climate since the 1960s is found in the global oceans, and more than three quarters of Earth's water exchange via precipitation and evaporation occur over the oceans [2] [4]-[8]. While estimates vary, the global oceans have absorbed about a quarter to a third of total anthropogenic emissions of carbon dioxide from fossil fuel burning, cement production, and land use changes, thereby slowing the rate of climate change [4] [9]-[11]. Changes in ocean temperatures can affect physiological functioning of marine ecosystems, altering the abundance and geographic distribution of plants and animals, which in turn can propagate into socio-economic systems dependent upon those marine species [12]-[16]. Changes in ocean temperatures can also impact the frequency and intensity of extreme events (e.g., tropical cyclones) on shorter time scale [17]-[19], and are closely linked to climate variability and change on time scales of seasons to decades and longer (e.g., El Niño-Southern Oscillation [ENSO], the Pacific decadal oscillation [PDO], the Atlantic multidecadal oscillation [AMO], and the North Atlantic oscillation [NAO]) [4] [20]-[23]. The large thermal inertia of the ocean also reduces the signal of short-term variability, providing a clearer signal of long-term temperature changes that are ideal for the detection and monitoring of long-term climate change [4] [24] [25].

Given that the ocean surface represents the thermal conditions of both the upper ocean and lower troposphere and that there is now a greater than 160-year continuous record of in situ global sea surface temperature (SST), sea surface temperatures are widely used as a fundamental physical parameter to represent the oceans in climate studies and monitoring [22]-[24] [26] [27]. Early in situ SST observations were derived from ships by using "partially-insulated" wooden buckets to collect water from which temperatures were sampled [22] [28]. Use of wooden buckets transitioned to the use of predominantly "uninsulated" canvas buckets in the 1920s, and then to “insulated" rubber buckets in the 1950s and 1960s [22] [28] [29]. In the early 1930s, engine room intake (ERI) temperatures (i.e., measurements from seawater pumped into the ship to cool the engines) began to be entered into meteorological logs, with ERI SST measurements eventually becoming more numerous than those from buckets by the early 1980s. In the past few decades, the number of hull sensors-temperature sensors mounted to the inside or outside of the hull-have increased, but still remain relatively uncommon [22] [29]-[31]. SST observations from drifting and moored buoys increased through the 1980s, and now collect around $90 \%$ of all SST observations [21] [31]-[33]. These in situ SST observations have been complemented by satellite measurements of SST since 1970, with nearly global coverage by infrared sensors since the early 1980s. While satellite observations are not in situ, in situ data are often used to calibrate and validate satellite SST measurements [21] [25] [34] [35].

Given that SSTs have been observed by diverse methods since the mid-19th century, measurements are prone to systemic physical biases arising from differing observing platforms and methods of observation, shifting geographical distribution of observations, and changes in instruments with differing accuracies and measuring depth [4] [23] [31] [36] [37]. For example, bucket data tend to have cool biases (especially pre-1942) due to latent, sensible, and radiative heat transfer associated with the buckets. The magnitude of the bucket cooling biases depends upon the bucket construction, the ambient conditions, and observation practices [22] [28] [30] [31] [36]. In contrast, ERI observations tended to have warm biases, potentially related to the proximity to the ship's engine, the depth of the intake water, and the accuracy and precision of thermometers and their readings [22] [30] [36] [37]. Buoy observations of SST, moreover, tend to possess a cool bias relative to the ship-based measurements that necessitates adjustments to SST analyses to account for differing observation methods over time [21] [30] [37]-[39]. Biases with SST observations such as these must be identified, quantified, and adjusted to provide accurate measurements of SST [4] [23] [36] [37]. A full review of the SST measurement practices, biases, and adjustments applied to in situ SST data, however, is beyond the scope of this paper, and for further information the reader is encouraged to refer to comprehensive articles on the datasets [21]-[23] [30]-[32] [37].

While uncertainties and time-dependent biases are known to exist within in situ SST observations, gridded SST datasets that quantitatively adjust for these biases and contain estimates of bias uncertainties have been developed, with uncertainties small enough to assess climate change [26] [30] [38]-[40]. While not a complete listing of all SST datasets, some recent historical in situ reconstructions extending back until the 19th century include: the Kaplan Extended SST version 2 dataset (Kaplanv2, [41] [42]); the Hadley Centre SST version 3 (HadSST3, [32] [37]) and Sea Ice and SST version 1 datasets (HadISST1, [43]); the Centennial in Situ Observa- 
tion-Estimates of SST dataset (COBE-SST2, [44]); and the Extended Reconstructed Sea Surface Temperature version 4 dataset (ERSST.v4, [23] [27]). Despite these datasets using different raw data holdings, distinct methodological approaches to quality assurance and control, and differing adjustments to known biases [23] [27] [32] [37] [41]-[44], the various reconstructions show similar spatial and temporal patterns of SST, although some discrepancies exist when the spatial and temporal distribution of observations are limited (e.g., the early record for the eastern equatorial Pacific) [23] [24] [26] [40] [44] [45]. Globally, SSTs warmed from 1900 to 1940, followed by a period with little trend or a slight cooling until the mid-1970s, and a warming until present [21] [24] [26] [43] [44] [46]. This pattern follows the global temperature curve over the past century quite closely (i.e., see [47]). Similar centennial-scale and decadal-scale warming, particularly since the 1970s, between independently derived SST reconstructions indicates that common signals are dependably represented in these datasets [2] [21] [40].

While an understanding of global SST changes over time are important, information on regional SSTs changes are more practical when considering effects on physical and biological systems, and associated socio-economic impacts [46] [48] [49]. With its abundance of renewable and nonrenewable resources, the Gulf of Mexico is one such region [50] [51]. The Gulf of Mexico, a semi-enclosed marginal sea, is part of the Western Hemisphere Warm Pool (WHWP) and serves as a pathway for the transport of heat, salt, and nutrients from the Caribbean Sea through the Florida Straits to the North Atlantic via the Loop Current, one of the strongest currents in the world [52]-[55]. The Gulf of Mexico has some of the most developed infrastructure for oil and gas production in the world, has one of the most active ports by tonnage in the world, has a diverse fishing industry that accounts for about one third of the fisheries production in the continental US, and supports an economically vital tourism industry [50] [51] [55]. Yet, the Gulf of Mexico is susceptible to a variety of natural hazards that are linked to climate variability and change, such as hurricanes [1] [51] [56]. Sea surface temperatures directly impact the development and intensity of hurricanes, and have shown multidecadal variations in activity [18] [19] [57]. Given the influence of SSTs on hurricane activity, the sustainability of regional commercial marine resources sensitive to changes in SST, and possible negative impacts on recreation and tourism industries in a coastal region with rapid growth in human population, it is vital to understand the long-term spatial and temporal patterns of SSTs [13] [19] [51] [58] [59].

Long-term historical trends and spatial patterns of in situ SST measurements that can be used to predict future Gulf of Mexico regional SST trends have been limited [15] [53]. Lluch-Cota et al. [15] is one of the few studies that have focused on the entire Gulf of Mexico using in situ SST observations. The authors found that SST changes in the Gulf of Mexico have not been homogeneous over time nor space; the northeast Gulf of Mexico cooled between 1910 and 2011, while the western Gulf of Mexico warmed ( 0.05 to $0.27{ }^{\circ} \mathrm{C} /$ decade) over that same period. Embedded within these overall trends, the authors found multidecadal variability, with a warming in the early 20th century followed by a cooling from the 1950s into the 1970s and then a subsequent warming. Del Monte-Luna et al. [59] identified a similar multidecadal SST variability (i.e., 60-year cycle) between 1900 and 2010 throughout their southwestern Gulf of Mexico study region, although shorter-term signals (i.e., <10 years) were more evident in the northern portion of their study area than the southern portion. Both Lluch-Cota et al. [15] and del Monte-Luna et al. [59] attributed the multidecadal oscillations, at least in part, to the cycle of the AMO, but did find that there were diverse trends within the Gulf of Mexico.

The multidecadal variability identified in these two studies using in situ SST data are generally supported by longer-term proxy data and shorter-term satellite observations. Studies using foraminiferal magnesium-to-calcium ratios $(\mathrm{Mg} / \mathrm{Ca})$, oxygen isotope ratios $\left(\delta^{18} \mathrm{O}\right)$ of speleothem calcite, coral $\mathrm{Mg} / \mathrm{Ca}$ and strontium-to-calcium ratios $(\mathrm{Sr} / \mathrm{Ca})$, coral $\delta^{18} \mathrm{O}$, and dendrochronology proxy data conducted in select sites within or near the Gulf of Mexico (e.g., the Pigmy Basin in the northern Gulf of Mexico; Dry Tortugas National Park in the southeastern Gulf of Mexico) have shown similar multidecadal SST variability to that of the instrumental record and an overall warming during the 20th century [51] [54] [60]-[62]. While proxy data can provide a long SST record (i.e., centuries to millenniums), these data are limited by the fact that they rely on discrete point sources that must be used to represent large regions, and often have courser temporal resolution (e.g., decadal) than in situ datasets. Satellite-derived datasets, in contrast, provide high spatial and temporal resolution of SSTs over large areas, but are available for only the past few decades (since 1980) [13] [42] [55] [63]. Similar to proxy and in situ data, satellite-based studies indicate that there has been a basin-wide warming in the Gulf of Mexico over the past few decades. However, considerable spatial and temporal heterogeneity exists regarding the direction and rates of change within the Gulf of Mexico [13] [14] [55] [64] [65]. 
Despite the physical, biological, and socio-economic importance of the Gulf of Mexico, comprehensive multidecadal studies with sub-annual temporal resolution for the entire basin are limited, particularly in comparison to some other regions (e.g., eastern equatorial Pacific and northern Atlantic Oceans). While Lluch-Cota et al. [15] and del Monte-Luna et al. [59] examined in situ SSTs for the Gulf of Mexico, Lluch Cota et al. [15] only examined the southwestern portion, and del Monte-Luna et al. [59] examined times series of SST anomalies throughout their study period (as opposed to just total changes in SST between 1910 and 2011) for only two locations in the Gulf of Mexico. Proxy- and satellite-based studies of SST have their own inherent limitations: the isolated sampling of proxy data-based studies may not capture the spatial heterogeneity of SSTs within the whole Gulf of Mexico [13]-[15] [25] [55] [63]; the lack of available satellite data prior to 1980 cannot provide a record long enough for the studies of multidecadal-scale climate variability and change [22] [51] [59]-[63]. Moreover, the differing temporal (i.e., sub-annual to decadal) and spatial natures of the data sources further complicate the ability to compare results of studies using these various data sources. As such, this research examines seasonal SST changes in a continuous in situ dataset from 1901 to 2010 for the entire Gulf of Mexico to determine changes in both temporal and spatial SST patterns. The specific research objectives are to 1) examine the spatial patterns of decadally averaged SSTs from 1901-2010, 2) determine SST trends over shifting periods between 1901 and 2010 across the entire Gulf of Mexico, and 3) compare the findings of this research to those of other previous research to understand the reasons for the spatially and temporally varying patterns of SSTs in the Gulf of Mexico. These types of information are vital for understanding past climate change and variability, as well as improving climate prediction, at scales relevant to understanding the Gulf of Mexico and sustaining the use of its natural resources. In subsequent research, patterns of coastal SSTs will be compared with air temperatures from adjacent land-based stations, and relationships between large-scale temperature changes in the Gulf of Mexico region and modes of interannual to interdecadal variability that potentially influence temperatures in the region (e.g., the Atlantic Multidecadal Oscillation) will be examined.

\section{Data and Methodology}

Because proxy techniques have a limited number of observations and satellite measurements of SST are only available for a few decades, in situ records of SST are the most viable means of examining spatial patterns of SST over decadal-to-century time scales. In situ measurements of SST, however, were not originally recorded for the purpose of climate monitoring, and there has been considerable variability in their spatial (e.g., shifting marine traffic) and temporal sampling (e.g., fewer observations during the World Wars) throughout their records [24] [25] [42]. Given the need to have a continuous and homogeneous time series for as long a period as possible to detect and quantify climate change and variability, historical observations must be adjusted to account for the changes in instrumentation and observation methods [24] [41] [44] [66]. As such, the current research uses monthly Extended Reconstructed Sea Surface Temperature, version 4 (ERSST.v4), data that have been adjusted for biases in the measurements [23] [27]. These monthly SST measurements are available as $2^{\circ} \times 2^{\circ}$ (latitude $\times$ longitude) gridded data for forty-one grid cells in the Gulf of Mexico since 1854 (Figure 1). While the ERSST.v4 (ERSST hereafter) are available since the mid-19th century, only data since 1901 are used in the current study because of the sparseness of data and uncertainty with its adjustment before that date [23] [27] [44]. Data prior to 1951 also contains fewer observations, particularly during the two World Wars [21] [31] [38] [42], and results obtained with these data should be interpreted with caution, as has been done in this research.

The ERSST reconstruction was selected over other analyses (e.g., Kaplanv2; HadSST3; HadISST1; COBE-SST2) because of its spatial resolution, the fact that is has been recently updated, and its ability to be compared to the two other historical in situ studies conducted on the Gulf of Mexico. The Kaplanv2 and HadSST3 reconstructions are only available as $5^{\circ} \times 5^{\circ}$ gridded data, which is too course for a study of this nature. The HadSST3 reconstruction also does not interpolate for missing data, so gaps in data coverage exist earlier in its record. While the HadISST1 and COBE-SST2 analyses are available with $1^{\circ} \times 1^{\circ}$ spatial resolution, they are based upon the same raw SST measurements of the International Comprehensive Ocean-Atmosphere Data Set (ICOADS; [67]) that is only available as $2^{\circ} \times 2^{\circ}$ gridded data before 1960, and as such, they have been interpolated into the $1^{\circ} \times 1^{\circ}$ resolution made available and are not based upon original gridded data with higher spatial resolution. Moreover, the HadISST1 reconstruction has not been recently updated, and therefore, has not been adjusted for known post-1941 biases in SST observations [36] [39] [43]. The ERSST reconstruction has been recently updated to adjust for known biases in SST observations [23] [27], has a $2^{\circ} \times 2^{\circ}$ spatial resolution, and is a 


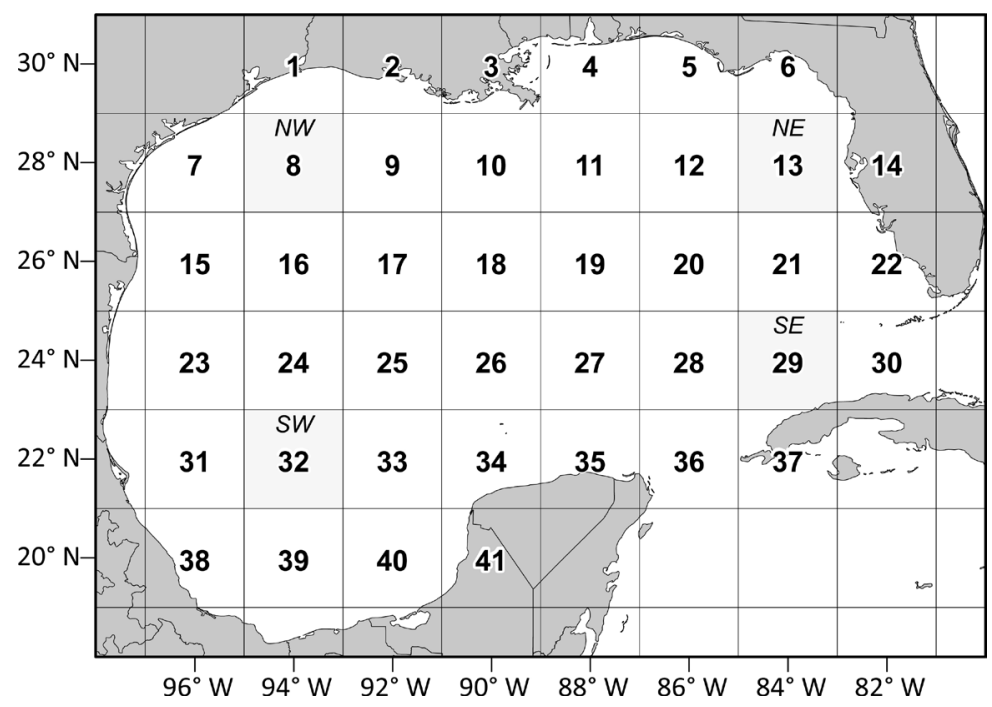

Figure 1. Spatial array of the forty one $2^{\circ} \times 2^{\circ}$ degree (latitude $\times$ longitude) grid cells used in the current study of SSTs in the Gulf of Mexico. Grid cells labelled with intercardinal directions (shaded) are those for which time series are examined in detail.

version of the same reconstruction used in previous research based on in situ SST observations (e.g., [15] [59]). Moreover, variations in the area-averaged SST anomalies at interannual and decadal times scales are broadly consistent with other reconstructions [23] [27], further justifying its use.

The monthly ERSST data were averaged seasonally (i.e., DJF, MAM, JJA, SON) for each year between 1901 and 2010, and for each grid cell in the Gulf of Mexico (GoM hereafter). Seasonal SSTs for each grid cell were averaged by decade (e.g., 1901-1910) for all decades during the study period. Decadally averaging the seasonal SSTs provides more robust spatial and temporal GoM SST patterns because the averaging reduces the impact of interannual variability, potential sampling biases in the early part of the record, and high-frequency events that are not indicative of overall SST changes in the GoM. Seasonal time series were also constructed for each grid cell, and the slope of the linear regression line was used to calculate the change in SSTs for all cells over the study period. In this case, we regressed the seasonal SSTs on the year of the season in question, using the standard seasons as winter (DJF), spring (MAM), summer (JJA), and fall (SON). In the case of winter, the year was assigned based on January and February, hence the winter of 1901 includes December of 1900, along with January and February of 1901. Given that SSTs in the GoM have not changed linearly through time [15] [18] [19] [51] [54] [57] [59]-[62], trends, and hence changes in SSTs, will vary depending upon the selected start date [4] [21] [24]. SST trends were therefore calculated using the start of each decade in the twentieth century through 1981 (i.e., 1901-2010, 1911-2010, ..., 1981-2010), but not 1991-2010 and 2001-2010 so that only longer term trends would be represented. This allowed for an examination of how SST trends varied over time throughout the GoM with decadally shifting starting dates, and would therefore better represent the temporal nature of SST changes in the GoM. Pearson correlation tests were also conducted on the entire study period, 1901-2010, to determine if the overall SST trends were statistically significant. The correlation represents the relationship between the seasonal SSTs and the year in which it occurs. A positive correlation coefficient notes that as years increase, SSTs increase. In contrast, a negative correlation indicates that as years increase, SST decreases. We use standard levels of significance at $\propto \leq 0.05$ and $\propto \leq 0.01$. Moreover, when examining the spatial patterns of both the decadally averaged SSTs and changes in SSTs over time, identifying sub-regional coherency to the patterns increases the reliability of the results.

\section{Results and Discussion}

Sea surface temperatures, represented by decadally averaged SST (2001-2010), in the Gulf of Mexico undergo a clearly identifiable seasonal cycle (Figure 2). In summer, the GoM experiences uniformly warm temperatures (i.e., $29^{\circ} \mathrm{C}-30^{\circ} \mathrm{C}$ ) as the surface waters of the entire GoM are heated by solar radiation and a downward positive heat flux [53] [55] [68] [69]. SSTs during winter, in contrast, show a marked latitudinal gradient (slightly tilted 

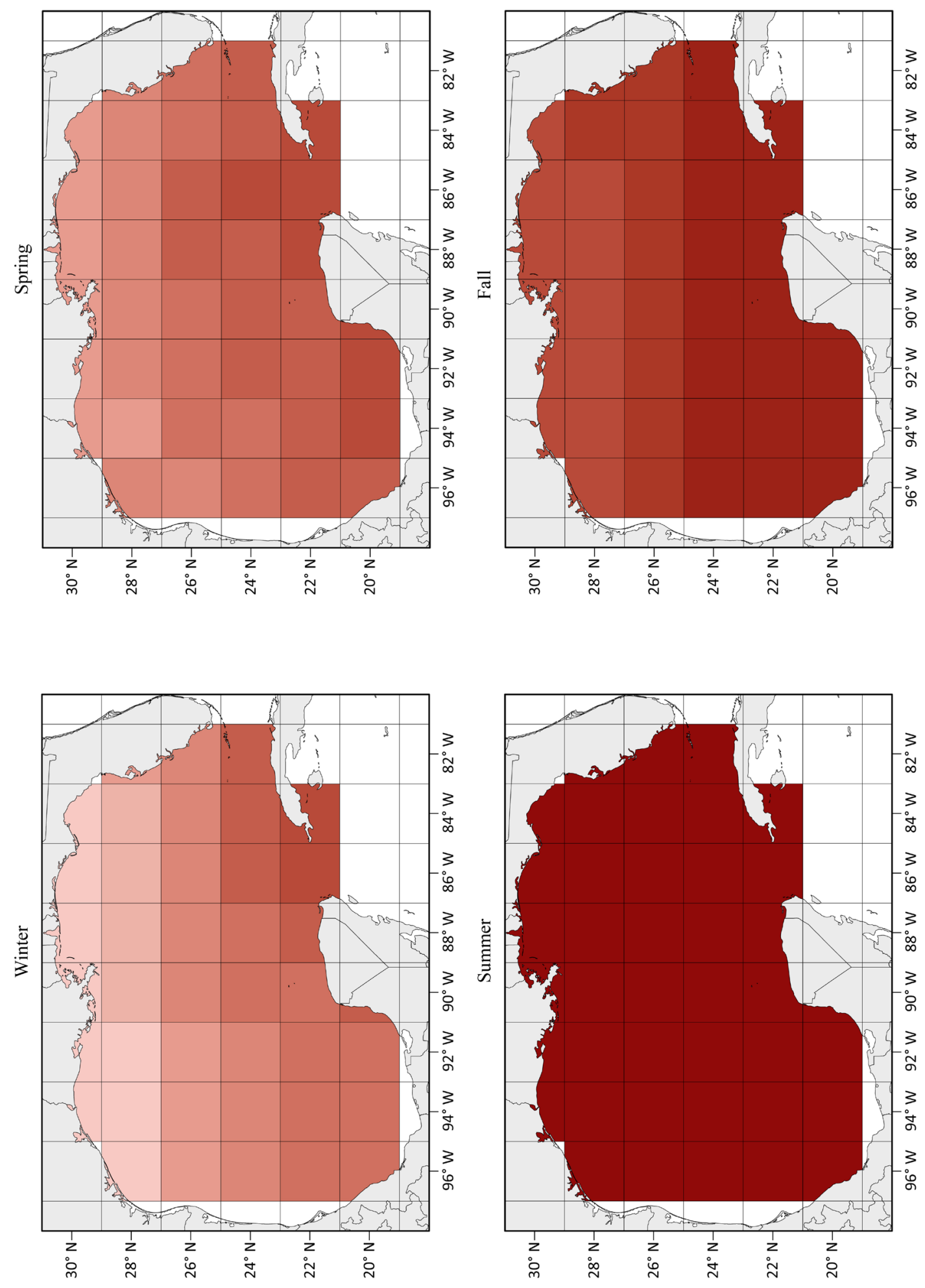

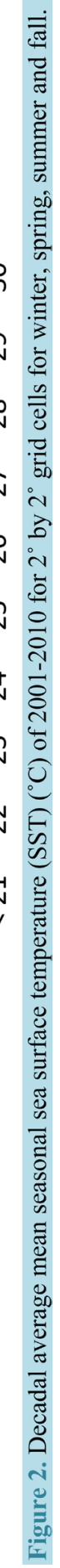


counter-clockwise) of nearly $7^{\circ} \mathrm{C}$ (i.e., $\sim 19^{\circ} \mathrm{C}-\sim 26^{\circ} \mathrm{C}$ ) between the cooler waters of the northern GoM and the warmer waters of the southern GoM due largely to reduced insolation and an upward negative heat flux. Heat loss from the surface in winter is further enhanced by storms and cold air masses from the north, and wind-driven convective mixing with cooler subsurface water [53] [55]. The Loop Current, transporting warmer waters from the Caribbean, prevents some of the cooling that would otherwise occur in winter, and consequently reduces the seasonal SST range in the eastern portion of the GoM relative to its western portion. The Loop Current was not visible in summer SSTs because the overall warming of the GoM masked the thermal gradient of the current at the surface [13] [53] [55]. Sea surface temperatures during spring and fall show transitional patterns, with spring (fall) most closely resembling those of winter (summer), which is to be expected given the lags involved in heating and cooling large water bodies such as the GoM.

The seasonal spatial SST patterns identified in the current research are consistent with those of both in situ (e.g., [15] [59]) and satellite-based observations (e.g., [13] [42] [55] [63]) of GoM sea surface temperatures. While the in situ SST reconstruction used in the current research does not have the fine spatial resolution of satellite-based observations (e.g., $4 \mathrm{~km}$ ), it does represent well the main SST patterns within the GoM, thereby confirming its usefulness to represent the spatial heterogeneity of the GoM SSTs. The in situ SST observations are also able to establish that spatial patterns of decadally averaged SSTs were consistent throughout the 20th century. Figure 3 (1901-1910) and Figure 4 (1951-1960) are representative of all decades during the study period (other decades not shown) and show the same general spatial patterns of SSTs throughout the GoM, although the SST magnitudes do vary by decade. The decade of the 1950s was slightly cooler than the decade of the 2000s, while the decade of the early 1900s was substantially cooler across the GoM, particularly during summer and fall when the warming of $\sim 0.9^{\circ} \mathrm{C}$ and $\sim 0.8^{\circ} \mathrm{C}$ (summer and fall, respectively) between the decades of the 1900s and the 2000s was greater than the global mean SST increase of $0.67^{\circ} \mathrm{C}$ over the past century [1]. In addition, the consistency of the spatial patterns of decadally averaged SSTs throughout the 20th century supports that the pre-1951 SST reconstructions are reliable even when observations were sparser.

Even though the spatial patterns were consistent, it does not necessarily imply that the timing and the rates of warming or cooling were uniform throughout the GoM. There was, in fact, a distinct seasonality to the trends, and the presence of opposing trends, within the GoM basin. For winter, there was a marked gradient with opposing trends orientated from northeast (cooling) to southwest (warming). Between 1901 and 2010, there was a warming throughout most of the GoM, with the greatest warming occurring towards the southwest $\left(\sim 0.4^{\circ} \mathrm{C}\right)$, and a very limited area of cooling towards the northeast (Figure 5). As the start date shifted decadally (i.e., 19112010 to 1921-2010 to 1931-2010), the areal extent of cooling expanded outwards from the northeast portion of the GoM and the magnitude of the cooling increased to $\sim 0.5^{\circ} \mathrm{C}$ between 1931 and 2010 along the coast of Florida, while simultaneously the area that experienced warming retreated towards the southwest until it was no longer present during the 1931-2010 period (Figures 6-8). This tendency reversed between the periods 19412010 and 1961-2010 (Figures 9-11): the areal extent and magnitude of warming expanded outwards from the southwest (up to $\sim 0.5^{\circ} \mathrm{C}$ ) and those of cooling retreated and decreased (cooling reaching $\sim 0.3^{\circ} \mathrm{C}$ ) towards the northeast portion of the GoM. During the remaining two periods (i.e., 1971-2010 and 1981-2010) the cooling amplified and the warming lessened slightly, with the boundary of these opposing trends situated through the center of the GoM (Figure 12 \& Figure 13). Overall, there was a multidecadal cycle where the areal extent and magnitude of cooling (warming) increased (decreased) for the periods 1901-2010 through 1931-2010 (19412010 through 1961-2010) and 1971-2010 through 1981-2010.

While the spatial patterns for the summer season also appeared to have a multidecadal cycle, the entire GoM has instead warmed regardless of the period examined and this warming was orientated from northwest to southeast. The strongest warming trend for the period 1901-2010 (Figure 5) was found along the Texas GoM coast (i.e., $>1{ }^{\circ} \mathrm{C}$ ) and the amount of warming decreased towards the southeast portion of the GoM along the Yucatan Channel between Mexico and Cuba $\left(\sim 0.8^{\circ} \mathrm{C}\right)$. This spatial pattern persisted during each period as the start date shifted (Figures 6-13), although the magnitude of the warming varied by $\sim 0.6{ }^{\circ} \mathrm{C}$ (southeast) to $\sim 0.8{ }^{\circ} \mathrm{C}$ (northwest) with different start dates. The warming was largest for the period 1901-2010 and the amount of warming decreased as the start date shifted to 1941 at which time the amount of warming ranged from $\sim 0.3^{\circ} \mathrm{C}$ in the northwestern and $\sim 0.1^{\circ} \mathrm{C}$ in the southeastern portions of the GoM (Figures 5-9). The amount of warming again increased over the periods 1951-2010 through 1971-2010 (Figures 10-12), reaching $\sim 0.7^{\circ} \mathrm{C}$ towards the northeast and $\sim 0.4^{\circ} \mathrm{C}$ in the southeast. For the last period (1981-2010), the spatial pattern persisted and the basin-wide amount of warming decreased by a little more than $0.1^{\circ} \mathrm{C}$ (Figure 13). The orientation of the SST 

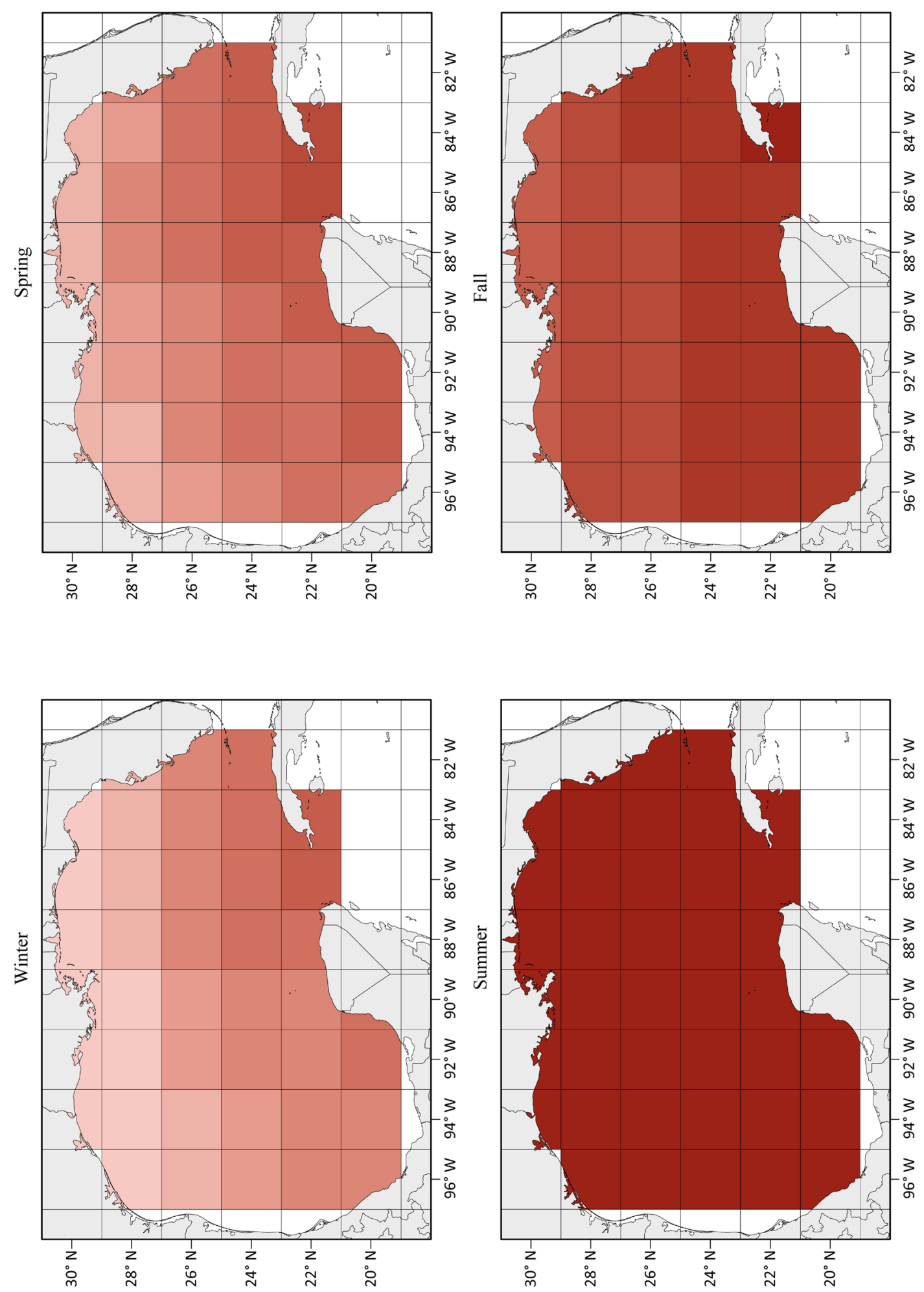

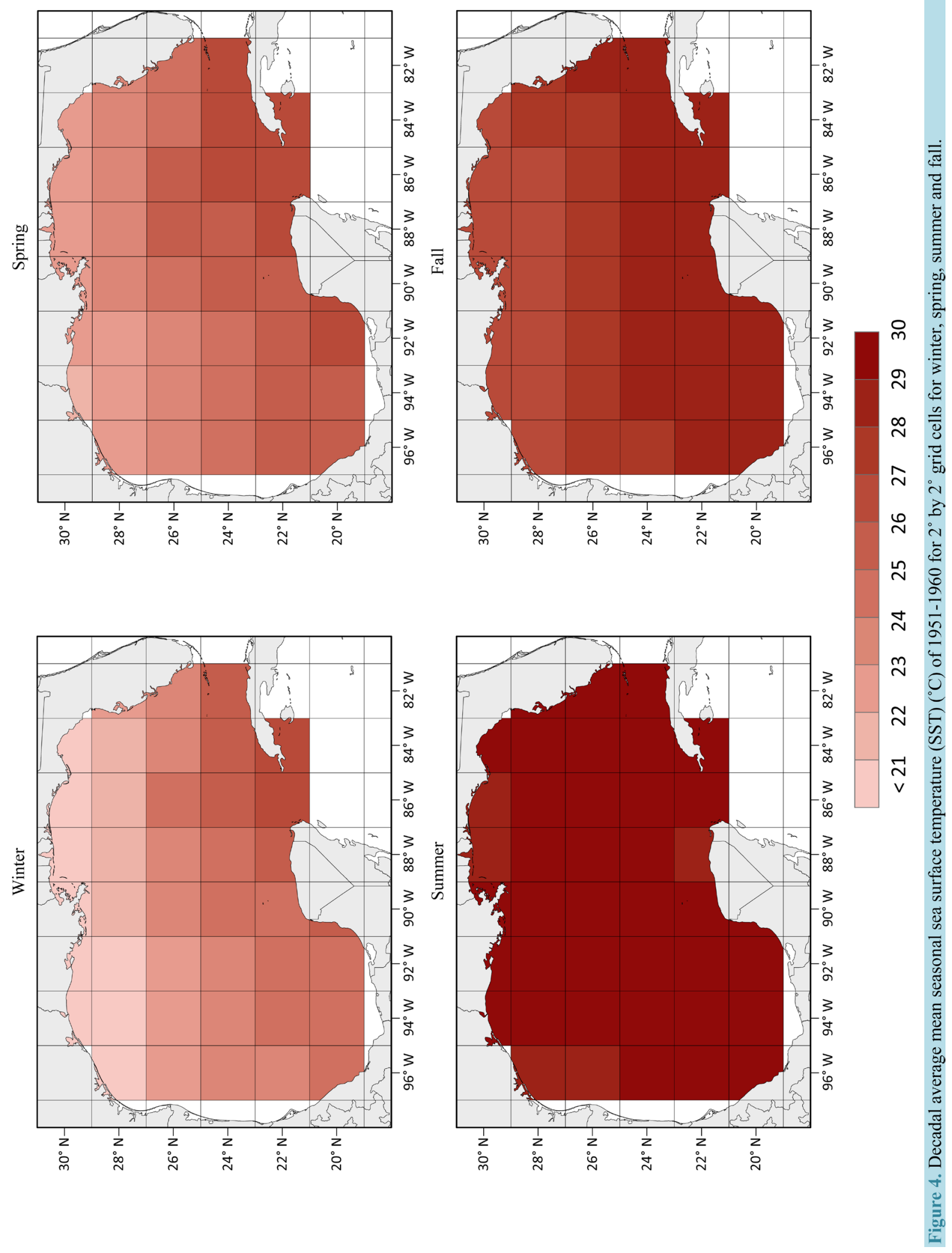
J. Allard et al.
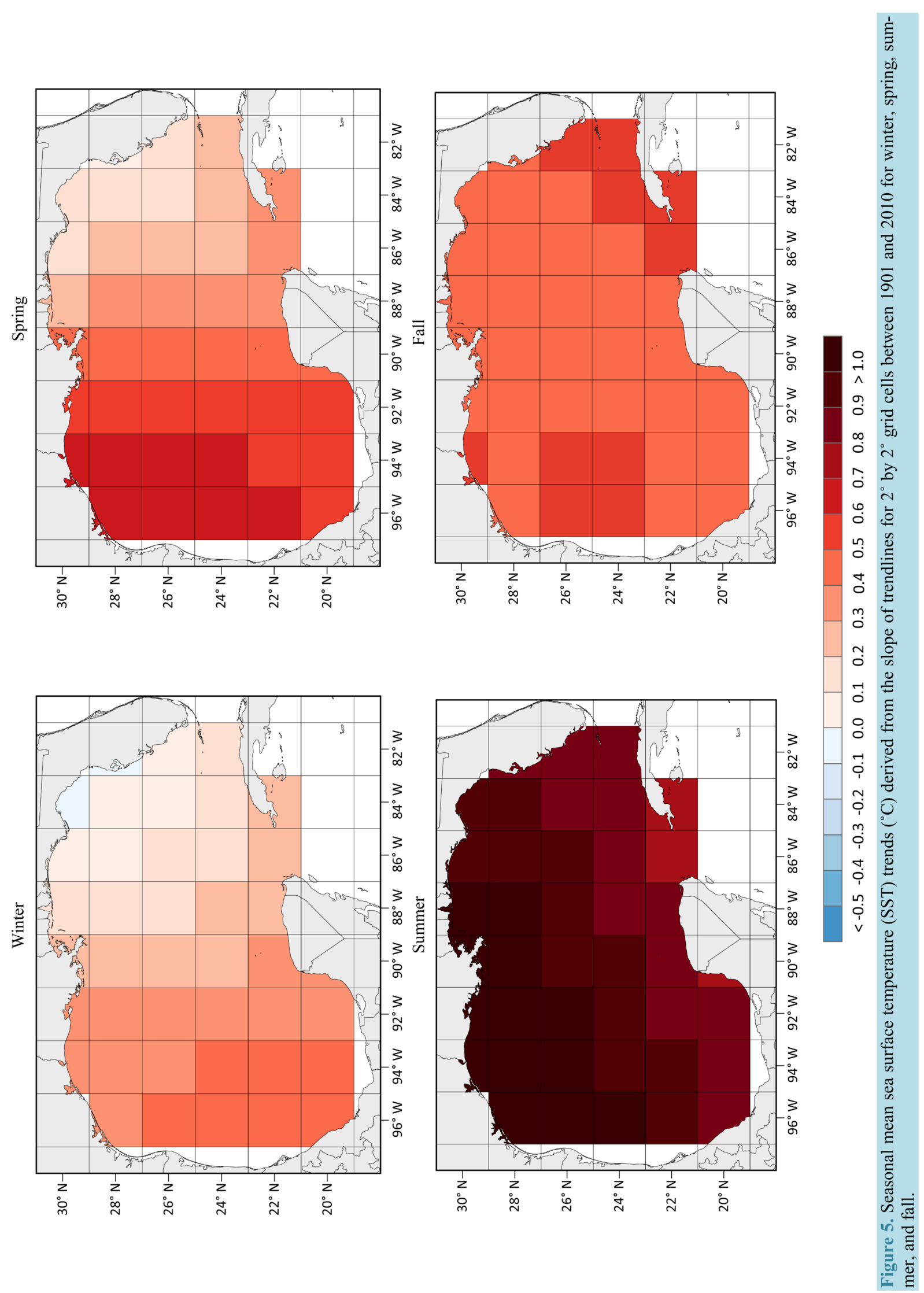

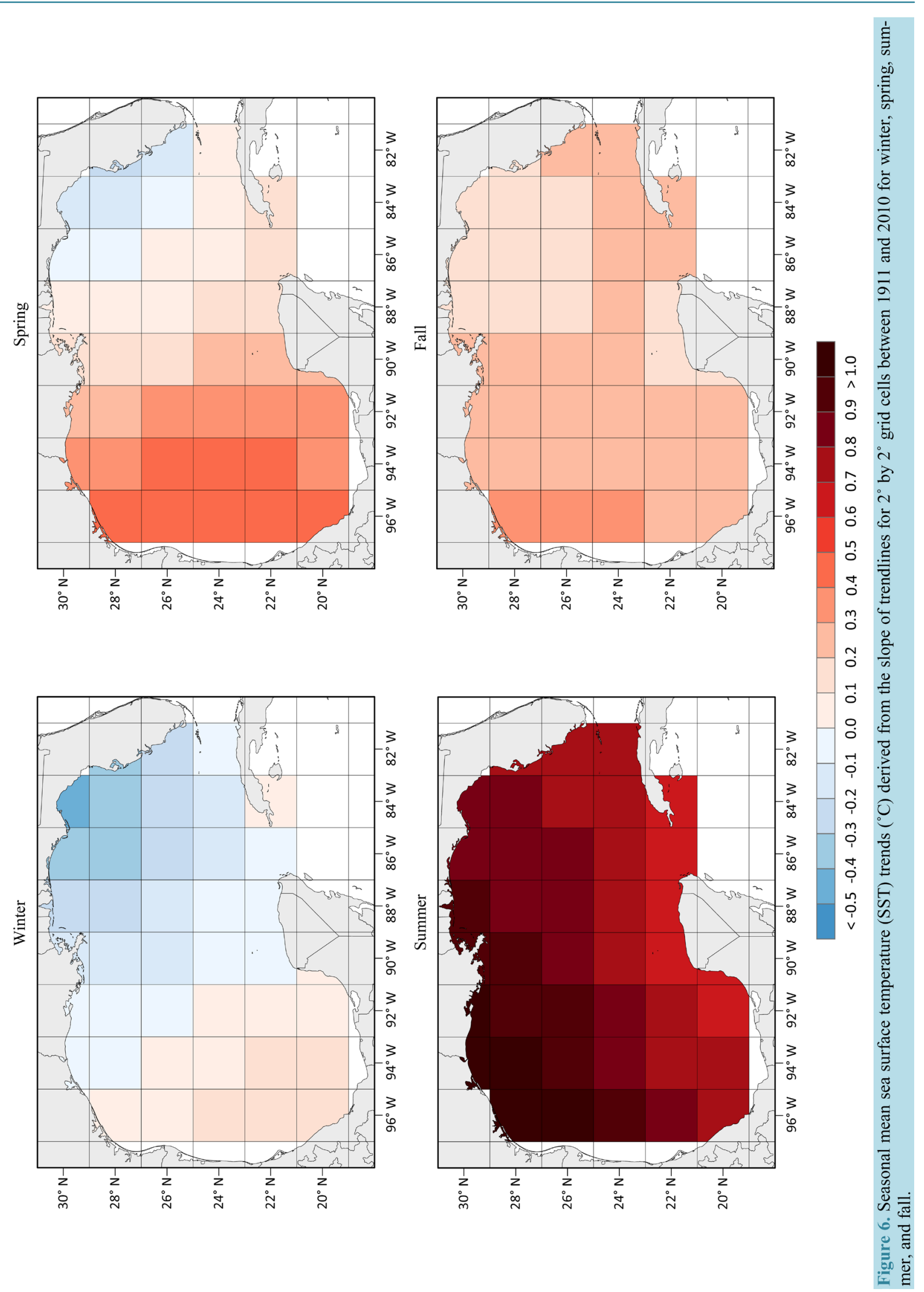
J. Allard et al.
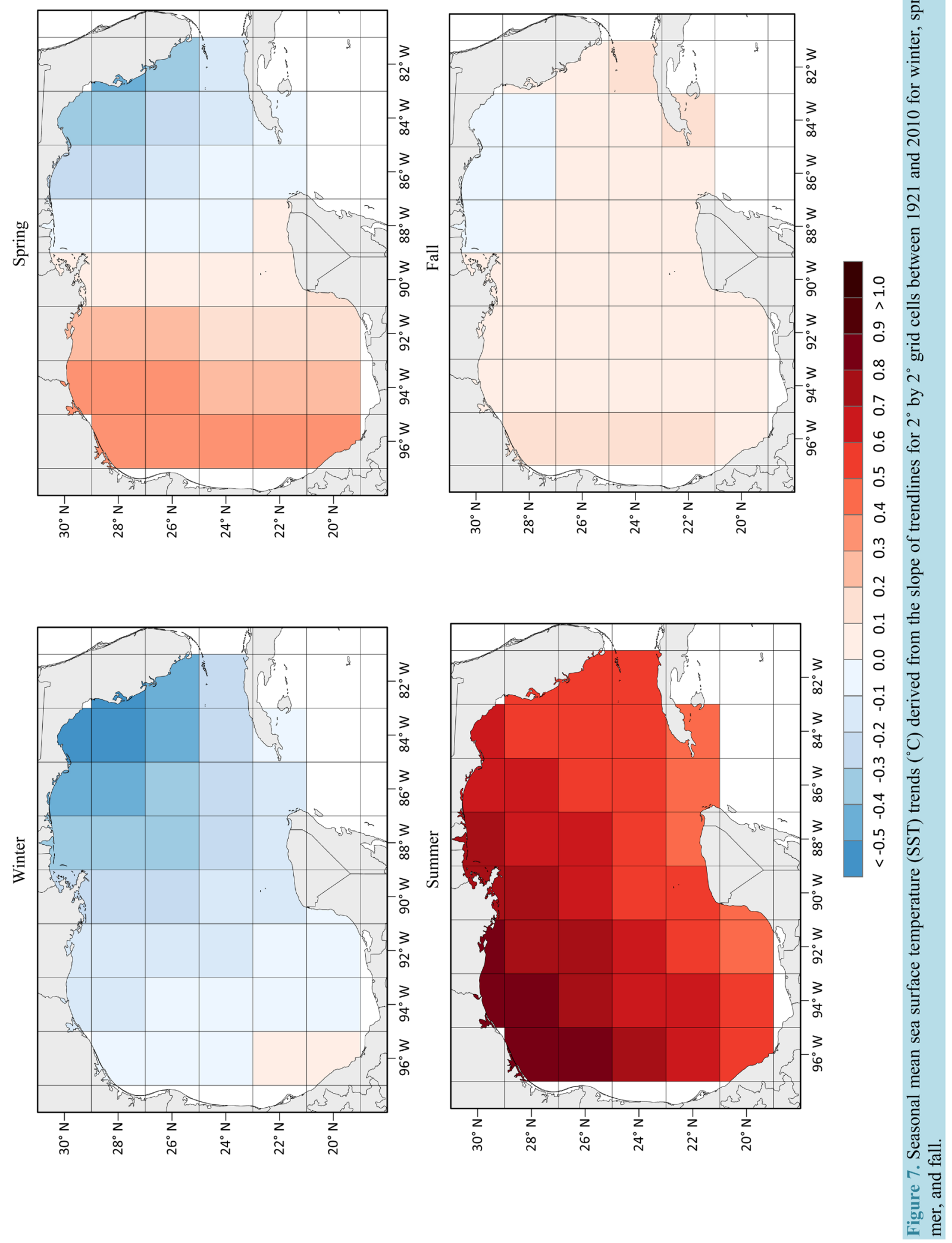

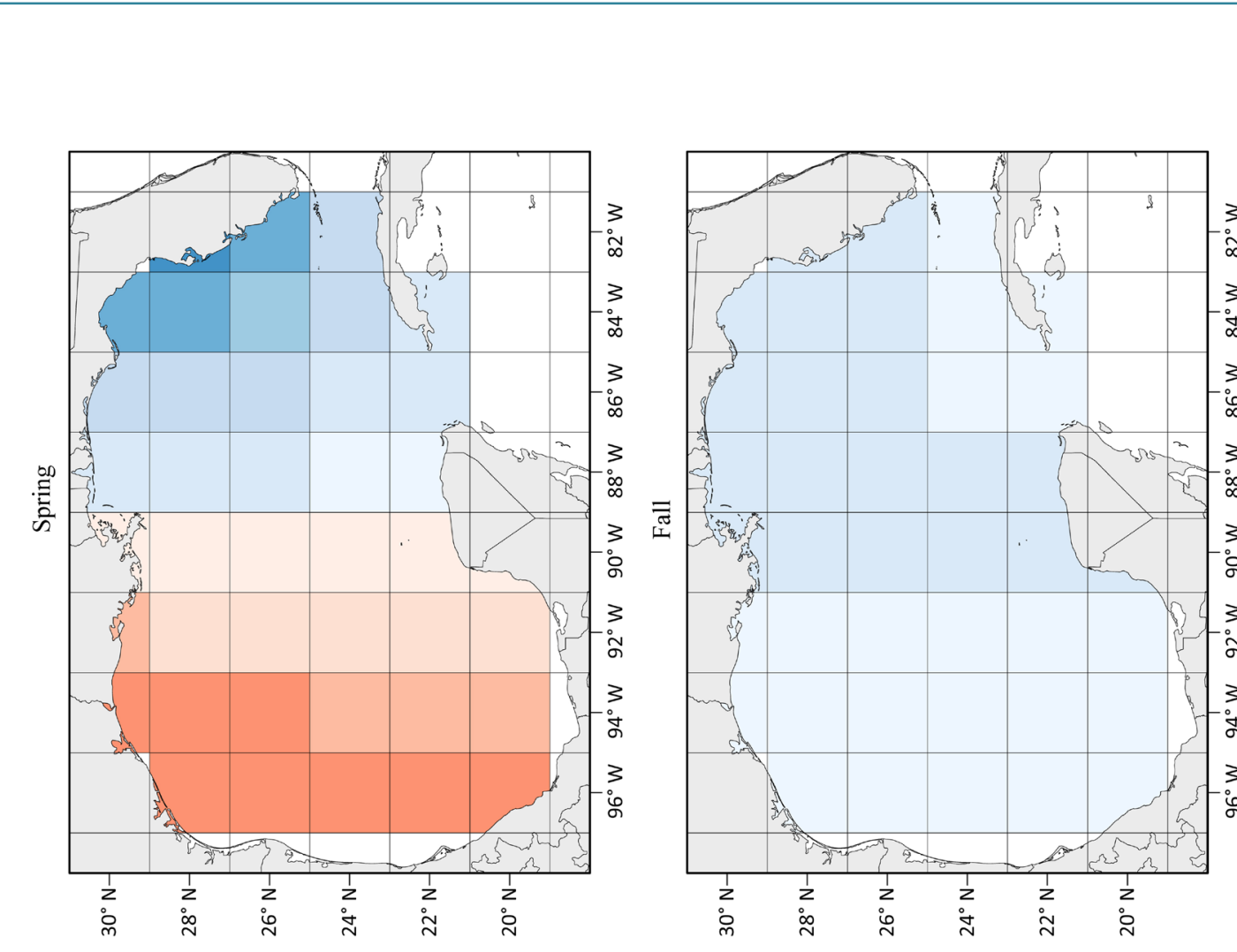

(2)
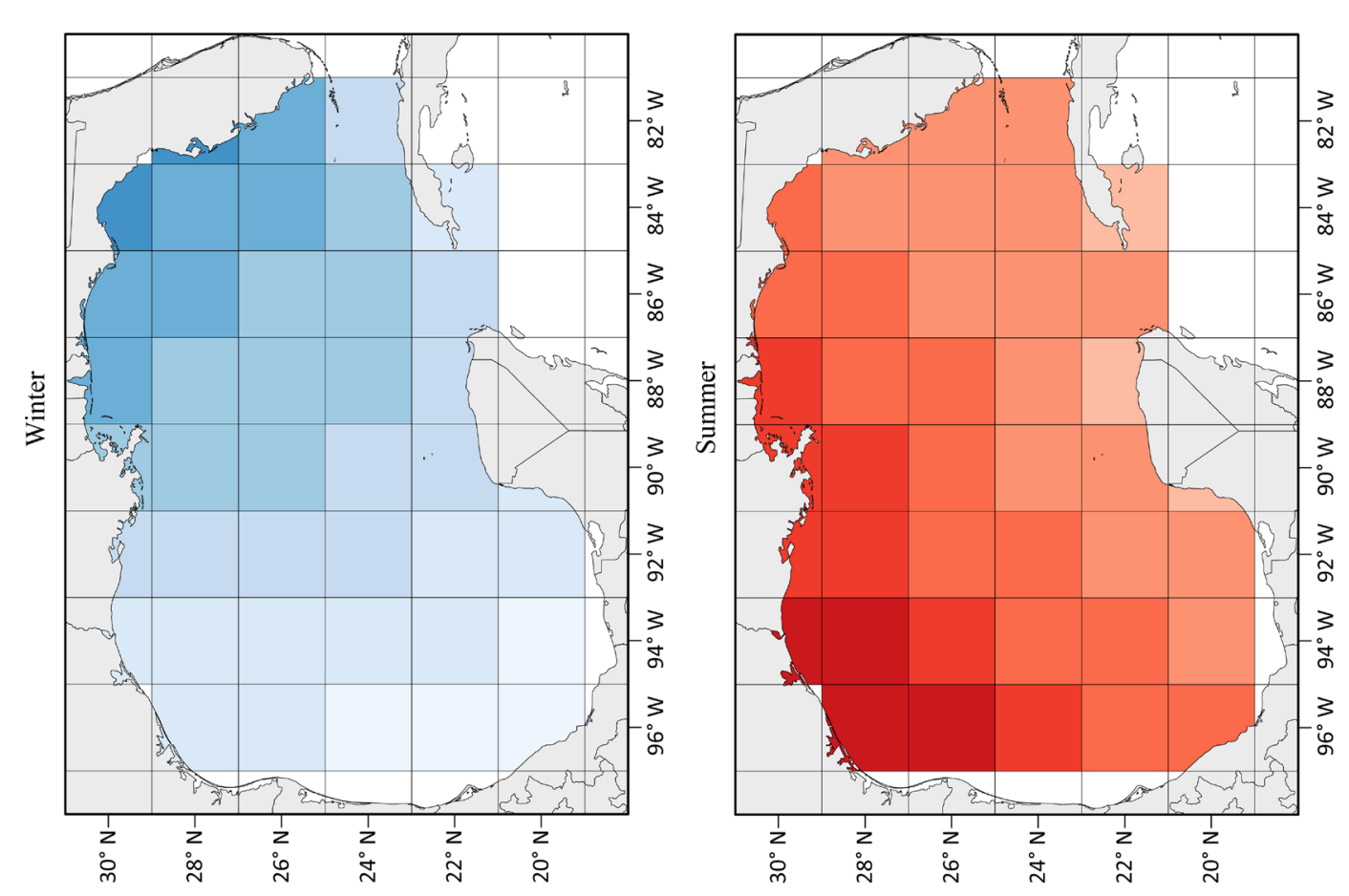

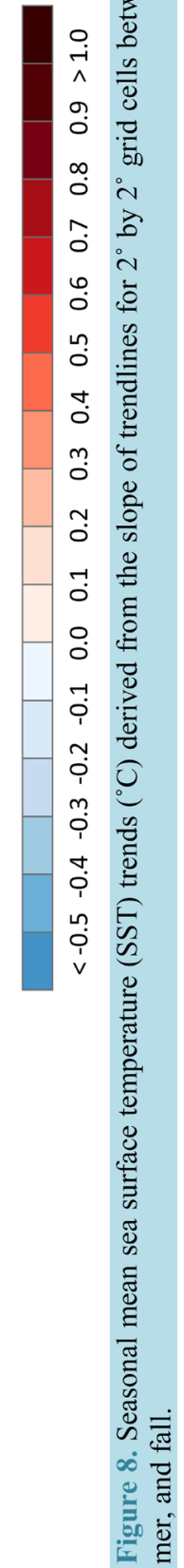


J. Allard et al.
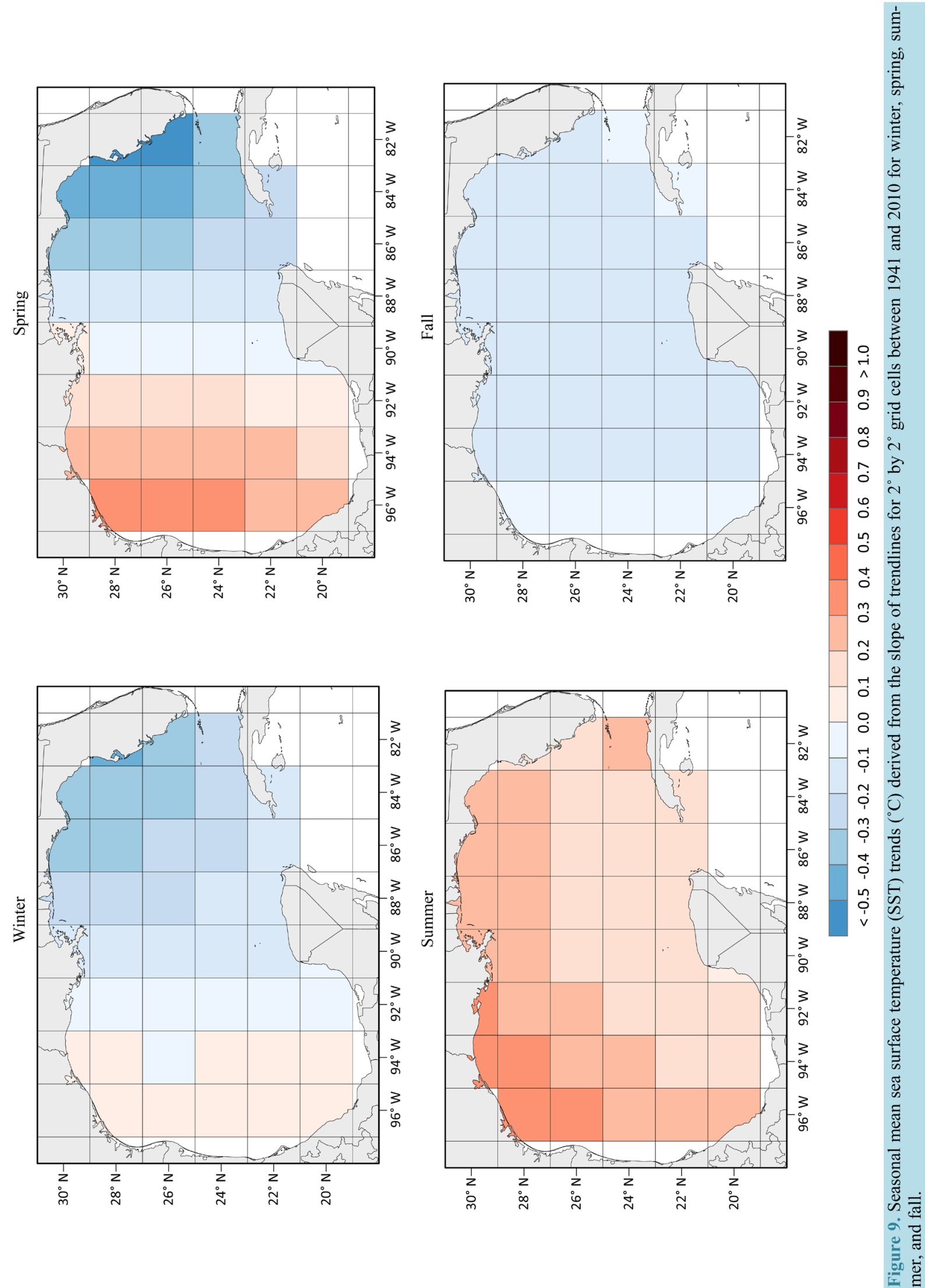

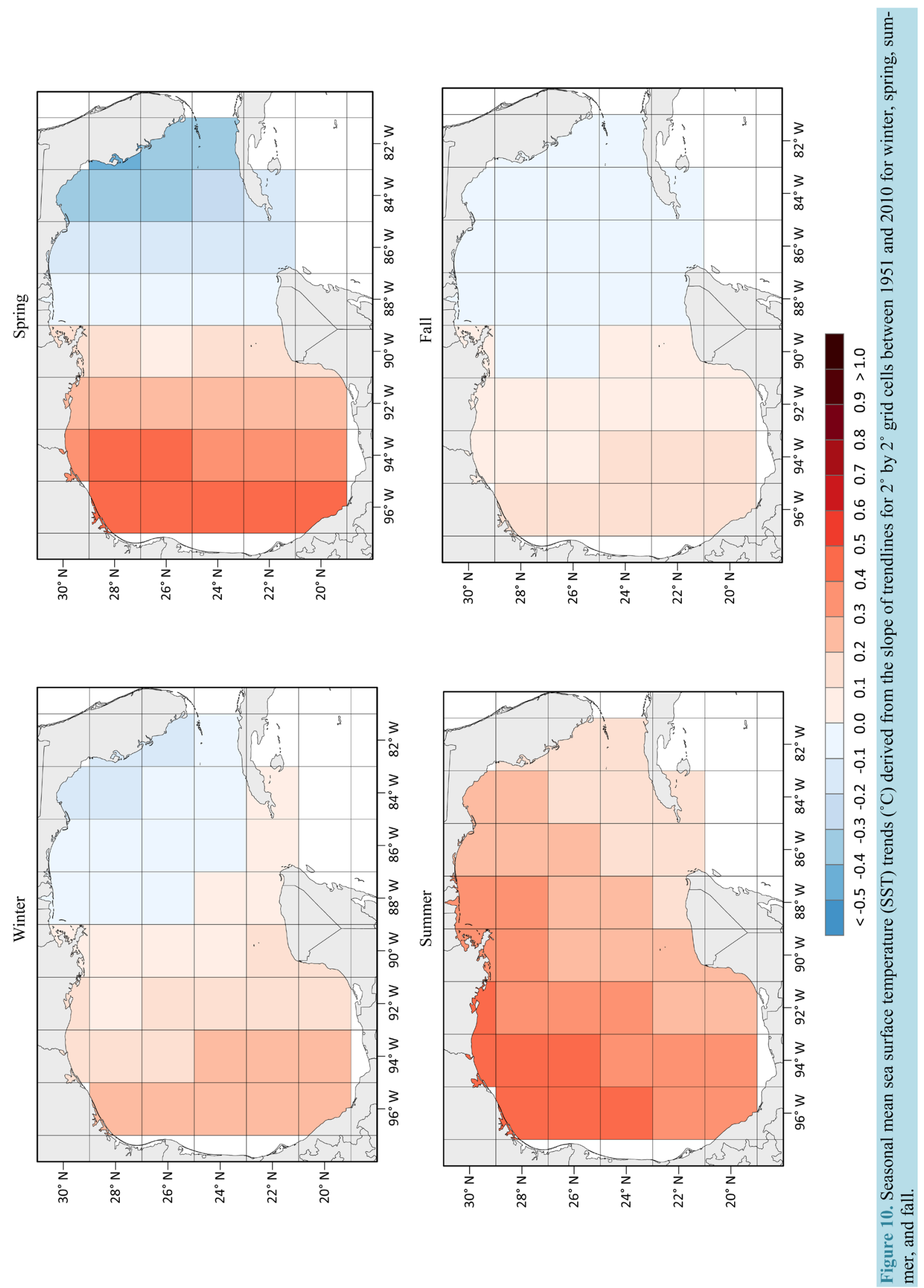
J. Allard et al.
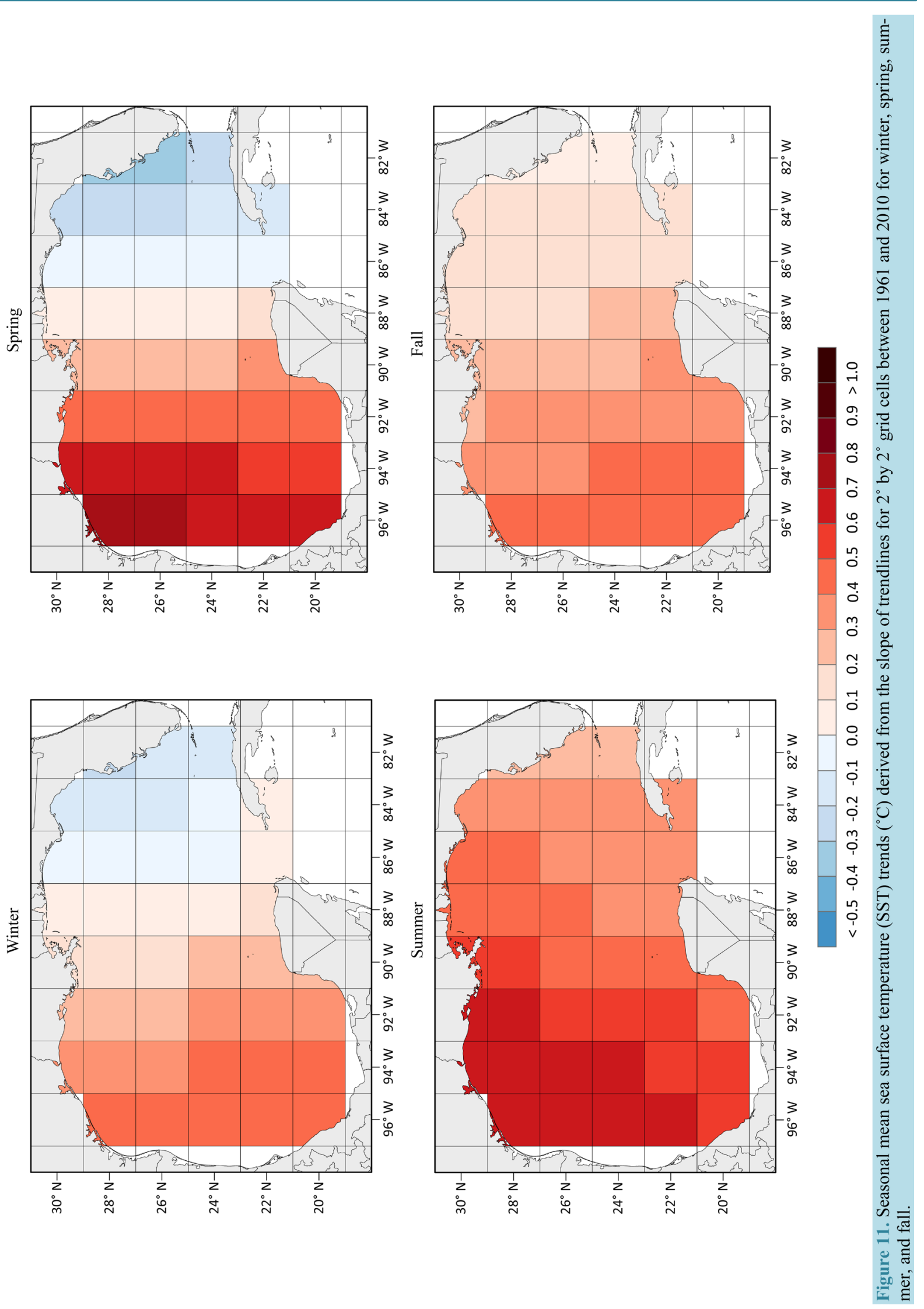

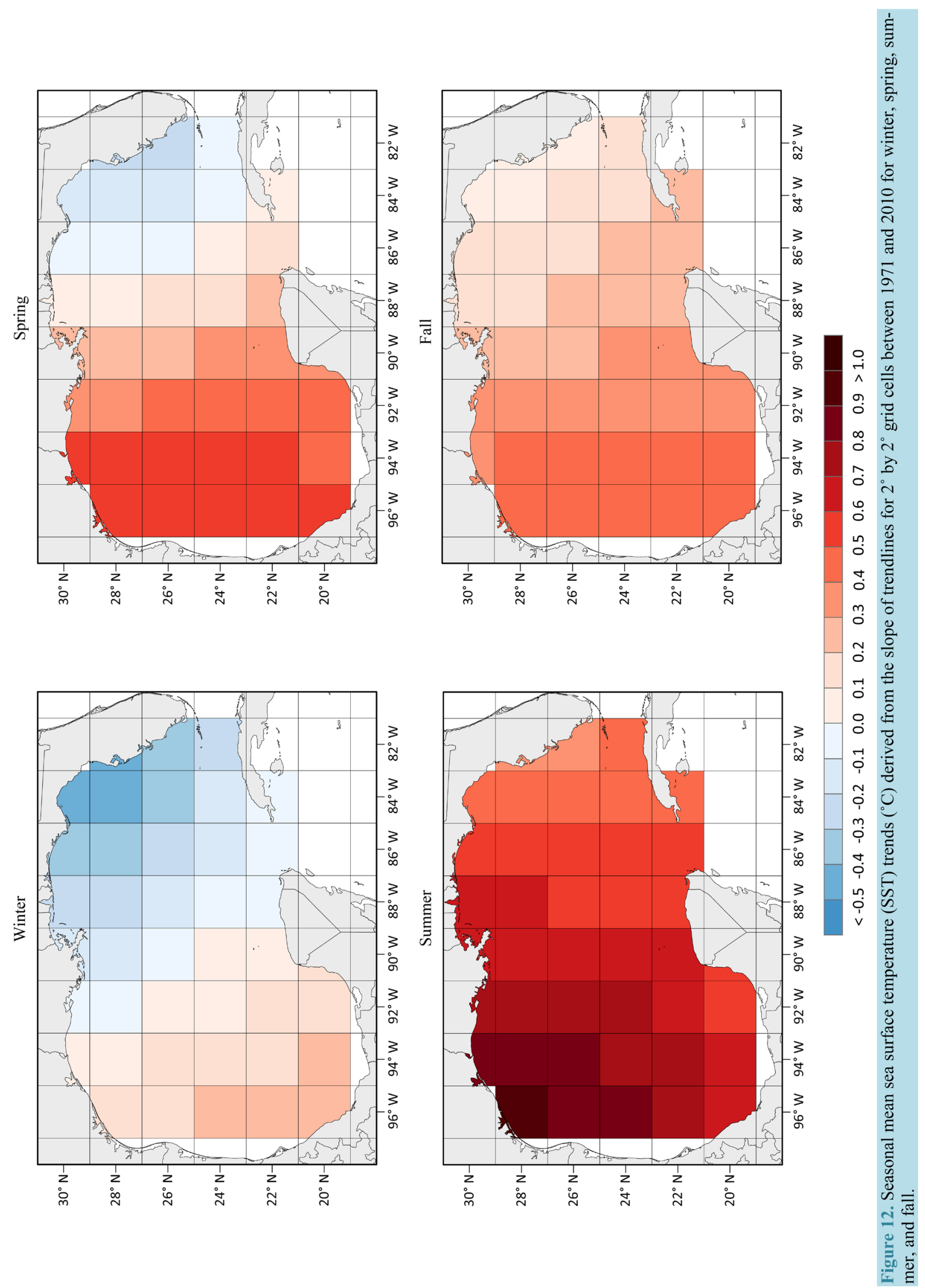
J. Allard et al.
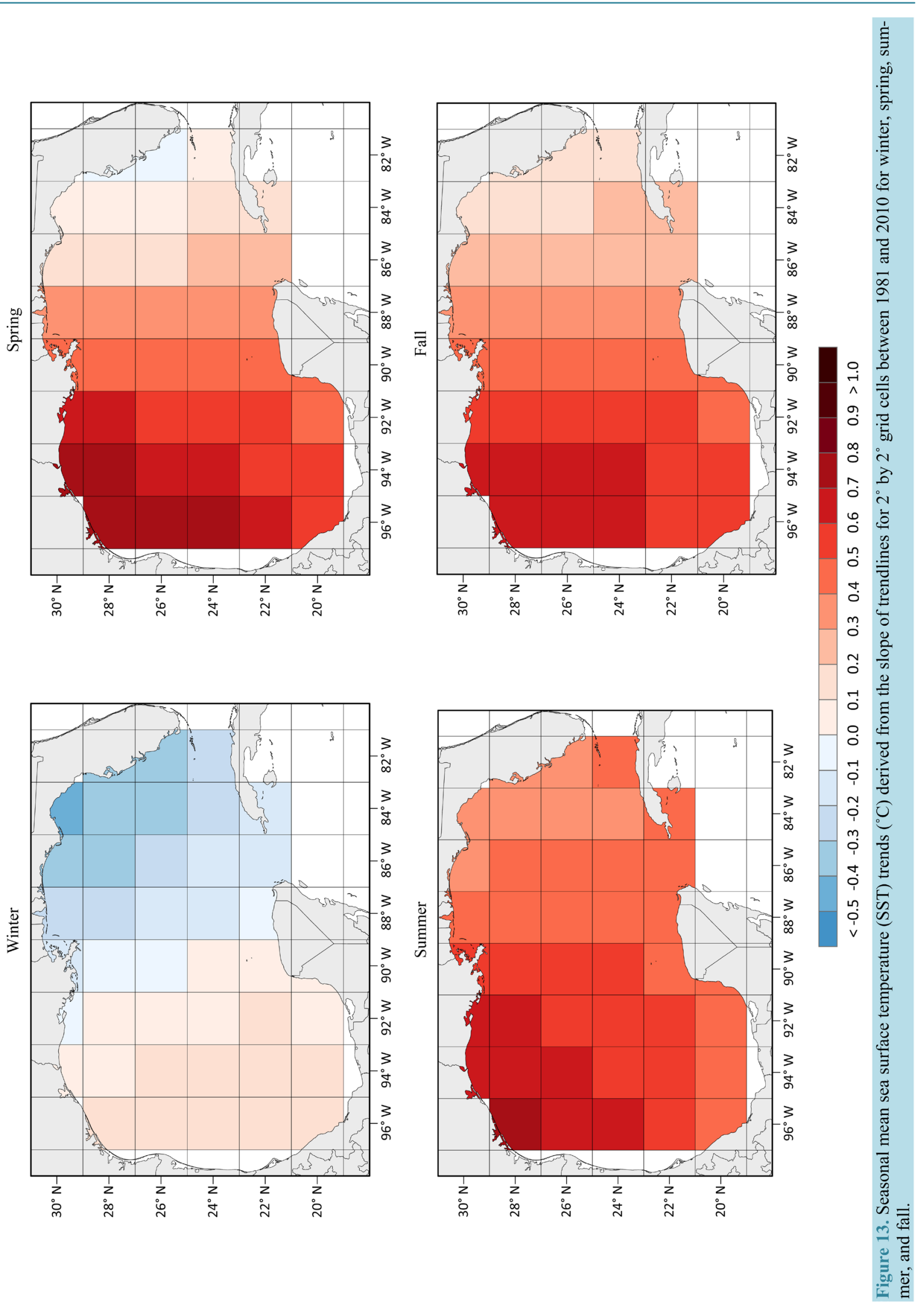
changes and opposing trends were not the only differences between winter and summer seasons: the timing of the multidecadal oscillations appeared slightly longer during summer and were offset a decade later; and absolute magnitudes of the SST changes over periods starting in the early 1900s were greater during summer than winter.

The spatial SST patterns during spring were similar to those of winter, although the areal extent and magnitude of the warming towards the west was greater than those of winter and the orientation was shifted to a more east-west orientation (Figures 5-13). As a transitional season, spring would logically exhibit patterns similar to those of winter (i.e., opposing SST changes), while also acquiring some characteristics that were present during summer (i.e., enhanced warming towards the west-northwest). Over the period 1901-2010 (Figure 5), there was warming throughout the entire GoM, with the greatest warming towards the west $\left(\sim 0.6^{\circ} \mathrm{C}\right)$. An area of cooling appeared and expanded outwards from the northeastern GoM for the periods 1911-2010 through 1941-2010 (Figures 5-9). The amount of warming (cooling) was, however, greater in the western (eastern) GoM by about a couple tenths ( a tenth) of a degree Celsius than in winter. The areal extent and magnitude of warming expanded outwards from the western GoM until only a small region of cooling remained off the coast of Florida between the periods 1951-2010 and 1981-2010 (Figures 10-13). Similar to the warming with start dates early in the 20th century, the amount of warming in the western side during spring was greater than that of winter, matching that of summer by the period 1981-2010 (i.e., $\sim 0.7^{\circ} \mathrm{C}$ ). The multidecadal oscillation in the SST changes were present yet again during spring, with spatial patterns similar to those of winter and magnitudes of warming closer to those of summer.

The patterns of fall SST changes with start dates in the first half of the 20th century are not consistently similar to those for other seasons, but gradually resemble those for spring and summer with start dates during the second half of the 20th century. During the period 1901-2010, the entire basin warmed $\sim 0.5^{\circ} \mathrm{C}$ and there was little resemblance to the spatial patterns of other seasons (Figure 5). The amount of warming over the GoM decreased between the periods 1911-2010 (Figure 6) and 1921-2010 (Figure 7) by about a couple tenths of a degree Celsius, and there was a slight cooling from 1921-2010 in the northeast GoM that was similar, yet less substantial, than those of winter and spring. By the periods 1931-2010 (Figure 8) and 1941-2010 (Figure 9), however, fall trends again do not parallel those of other seasons and a slight cooling of $\sim 0.1^{\circ} \mathrm{C}-0.2^{\circ} \mathrm{C}$ occurred throughout the basin. A gradient orientated from east to west started to appear during the 1951-2010 through 1971-2010 periods (Figures 10-12). Initially (1951-2010), there was a slight cooling (i.e., $\sim 0.1^{\circ} \mathrm{C}$ ) in the east and a slight warming (i.e., $\sim 0.1^{\circ} \mathrm{C}-0.2^{\circ} \mathrm{C}$ ) in the western GoM. Stronger east-to-west gradients then developed during the 1961-2010 and 1971-2010 periods similar to those of spring, except that only a warming occurred (i.e., $\sim 0.1^{\circ} \mathrm{C}$ in the east to $\sim 0.5^{\circ} \mathrm{C}$ in the west). By the $1981-2010$ period, the SST gradient pattern was similar to those of spring and summer, with a warming of $\sim 0.1^{\circ} \mathrm{C}$ in the eastern and $\sim 0.7^{\circ} \mathrm{C}$ in the western portions of the GoM. Even though it was not until the second half of the 20th century that fall exhibited spatial patterns similar to those of other seasons, the magnitudes and gradients of SST changes were consistently reduced for start dates throughout the 20th century when compared to those of other seasons.

Each season, with the few exceptions for fall, exhibited spatial patterns that involved gradients with latitudinal and/or longitudinal components, or a combination of those components (e.g., northeast to southwest). As such, time series for grid cells from each of the intercardinal corners of the GoM would be representative of the broad SST changes in the GoM and can be examined to understand further SST changes between 1901 and 2010 (Figure 14). The SST trends are easiest to see for summer, and those trends most closely resemble global annual temperature trends (e.g., [47]): SSTs warmed from 1901 to 1940, followed by a period with little trend or a slight cooling until the mid-1970s, and then a warming until present. The northwestern GoM had the most warming from 1901 through 2010 because that region was cooler than other regions in the early 1900s, and because there was warming in the early part of the 21st century as well as the last few decades of the 20th century. Winter, in contrast, does not have the dramatic SST changes relative to summer (Figure 14). After the warming from 1901 into the 1940s and the subsequent cooling until the early 1970s, SSTs did not change appreciably. The 1930s and 1940s were the warmest period during the entire record, resulting in an overall cooling from then until present. The eastern portion of the GoM (i.e., NE and SE) even continued to cool over the last few decades, while the western GoM (i.e., NW and SW) exhibited a warming trend after the early 1970s.

Similar to the transitional season results presented earlier, the times series for the four grid cells in the GoM for spring showed trends similar to those of winter, while those for fall gradually became similar to those of summer. All the grid cells showed a warming during spring from 1901 through the 1940s that was followed by a 

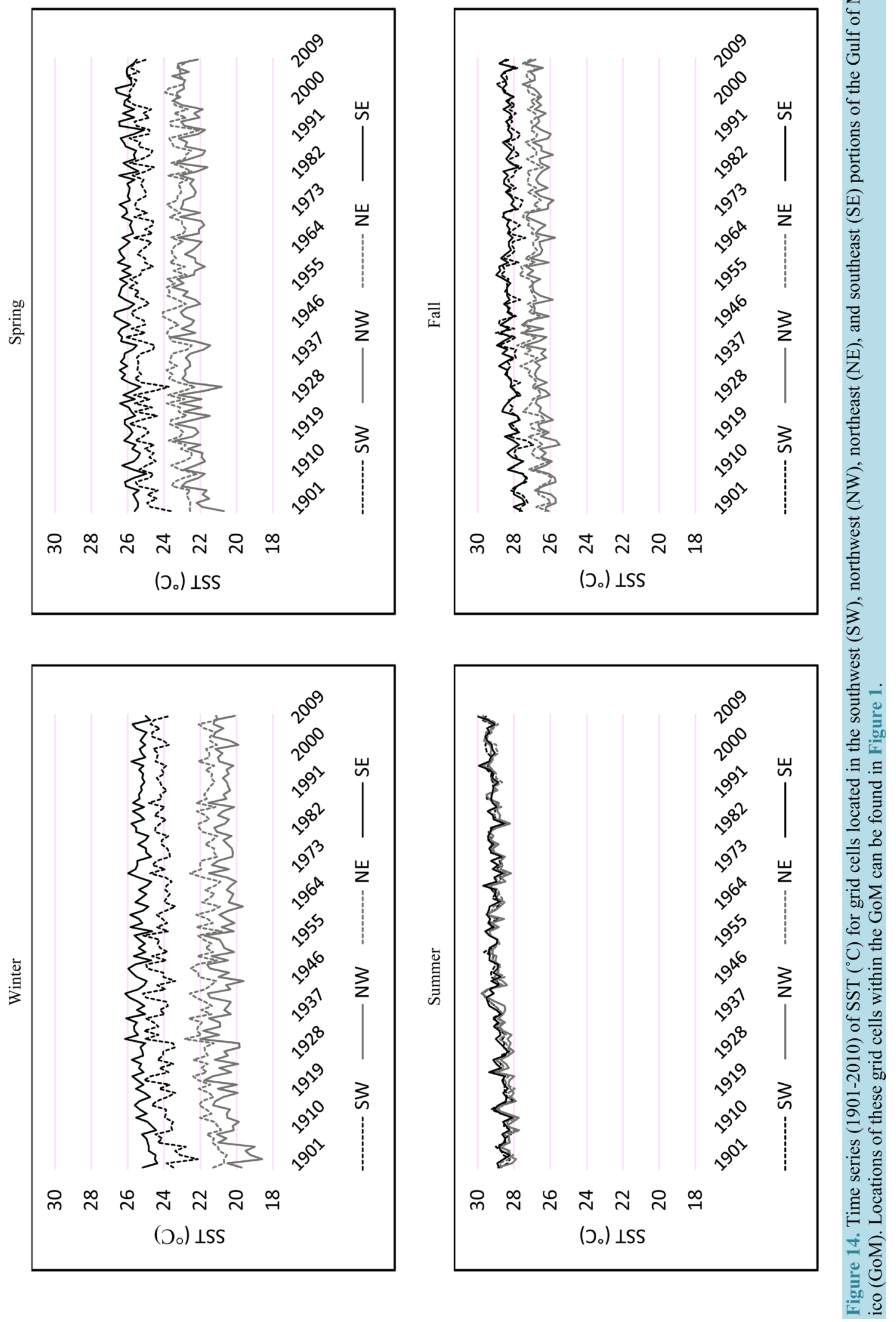
slight cooling until the 1970s (Figure 14). For the last several decades, spring SSTs remained essentially the same or continued to cool slightly in the eastern portion of the GoM, but warmed towards the west and northwestern portions of the GoM. The four grid cells also showed a warming during the fall from 1901 through the 1940s that was followed by a slight cooling until the mid-1970s (Figure 14). All four grid cells, however, warmed over the last several decades, with the largest fall warming occurring in the western and northwestern portions of the GoM.

The 1901-2010 time series data were tested for significance using Pearson correlations, with the seasonal value for each of the four individual grids being correlated with the year in which it occurred. Positive coefficients indicate that as time (year) progressed, SSTs warmed, while negative coefficients indicated the inverse, whereby a cooling trend was present. Twelve of the sixteen possible time series had statistically significant ( $\propto$ $<0.05)$ long-term (1901-2010) trends in SSTs (Table 1). The trends with the greatest statistical significance were found in summer, followed by fall, where all time series were significant at $\propto<0.01$. The northwest grid cell in summer had the highest level of explained variance at $\sim 47 \%$, while no variance was explained with statistical significance for the northeast grid cell in spring and all grid cells, except the southwest grid cell, in winter. As with how the four grid cells were representative of temperature trends throughout the GoM, the significance of the trends for the four grid cells also represented those of the entire GoM (Figure 15). The long-term (19012010) SST trends were all highly significant $(\propto<0.01)$ throughout the GoM in summer and fall where strong warming trends existed. In contrast, the level of significance for SST trends decreased away from the southwest portion of the GoM in winter and spring, until no significant trends existed towards the northeastern GoM where only slight warming or cooing had been present for the period 1901-2010.

To some extent, every season had SST changes with a multidecadal periodicity, as depicted in both the maps and time series. While the timing of the warming or cooling differed only slightly between the seasons, it was the magnitude of the warming or cooling that established the overall SST trends. For example, summer SSTs warmed from 1901 through the 1940s and again from the mid-1970s until 2010, with little trend or a slightly cooling from the 1940s to the mid-1970s. With the warmest decades occurring most recently and the lack of a strong cooling in the mid-20th century, all the periods (i.e., 1901-2010 through 1981-2010) showed a warming trend in summer. In contrast, winter SSTs did not warm, or warmed only slightly, over the last few decades, so the warmest temperatures in the 1930s and 1940s in the northeastern GoM resulted in a cooling trend in that area for the periods examined. With these differing rates of warming or cooling, the seasonal SST ranges (i.e., summer minus winter) were also affected (Figure 16). The largest seasonal differences occurred during the first decade when winter temperatures were at their coolest in the western GoM. Seasonal differences then decrease from the 1910s to the 1930s as it warmed throughout the GoM in all seasons, and was followed by increases in seasonal differences from the 1930s to 1970 when the cooling for winter was greater than that of summer. There is no clear increasing or decreasing trend for the seasonal differences post-1970, with natural interannual variability most likely causing the year-to-year differences that are visible. Regardless of the lack of a recent trend in seasonal SST differences, the differences in the magnitudes of seasonal SSTs superimposed on the multidecadal periodicity of SSTs appeared to have imprinted a similar periodicity on the range of seasonal SSTs over a majority of the study period.

With the exception of fall early in the study period, the spatial changes in SSTs were systematic and cohesive as the decades progressed: areas of warming or cooling simultaneously grew and intensified or retreated and lessened with the multidecadal periodicity previously noted. Even for the fall season, during which the spatial patterns would change more abruptly with different start dates, there was spatial cohesion within each period

Table 1. Pearson correlation (r values) between yearly time series and their corresponding seasonal sea surface temperature $\left({ }^{\circ} \mathrm{C}\right.$ ) values over 1901-2010 for four grid cells located in the northwest (NW), northeast (NE), southeast (SE), and southwest (SW) Gulf of Mexico. Locations of these grid cells within the GoM can be found in Figure 1. Correlations significant at $\alpha \leq$ 0.05 are in italics and significant at $\alpha \leq 0.01$ in bold italics.

\begin{tabular}{ccccc}
\hline Grid Cell & Winter & Spring & Summer & $\mathbf{0 . 3 2 2}$ \\
NW & 0.182 & $\mathbf{0 . 3 0 2}$ & $\mathbf{0 . 6 8 9}$ & $\mathbf{0 . 6 5 5}$ \\
NE & 0.018 & 0.083 & $\mathbf{0 . 3 6 2}$ \\
SE & 0.139 & 0.190 & $\mathbf{0 . 4 3 7}$ & $\mathbf{0 . 6 6 2}$ \\
SW & $\mathbf{0 . 2 4 5}$ & $\mathbf{0 . 3 5 6}$ & $\mathbf{0 . 3 6 5}$ \\
\hline
\end{tabular}


J. Allard et al.
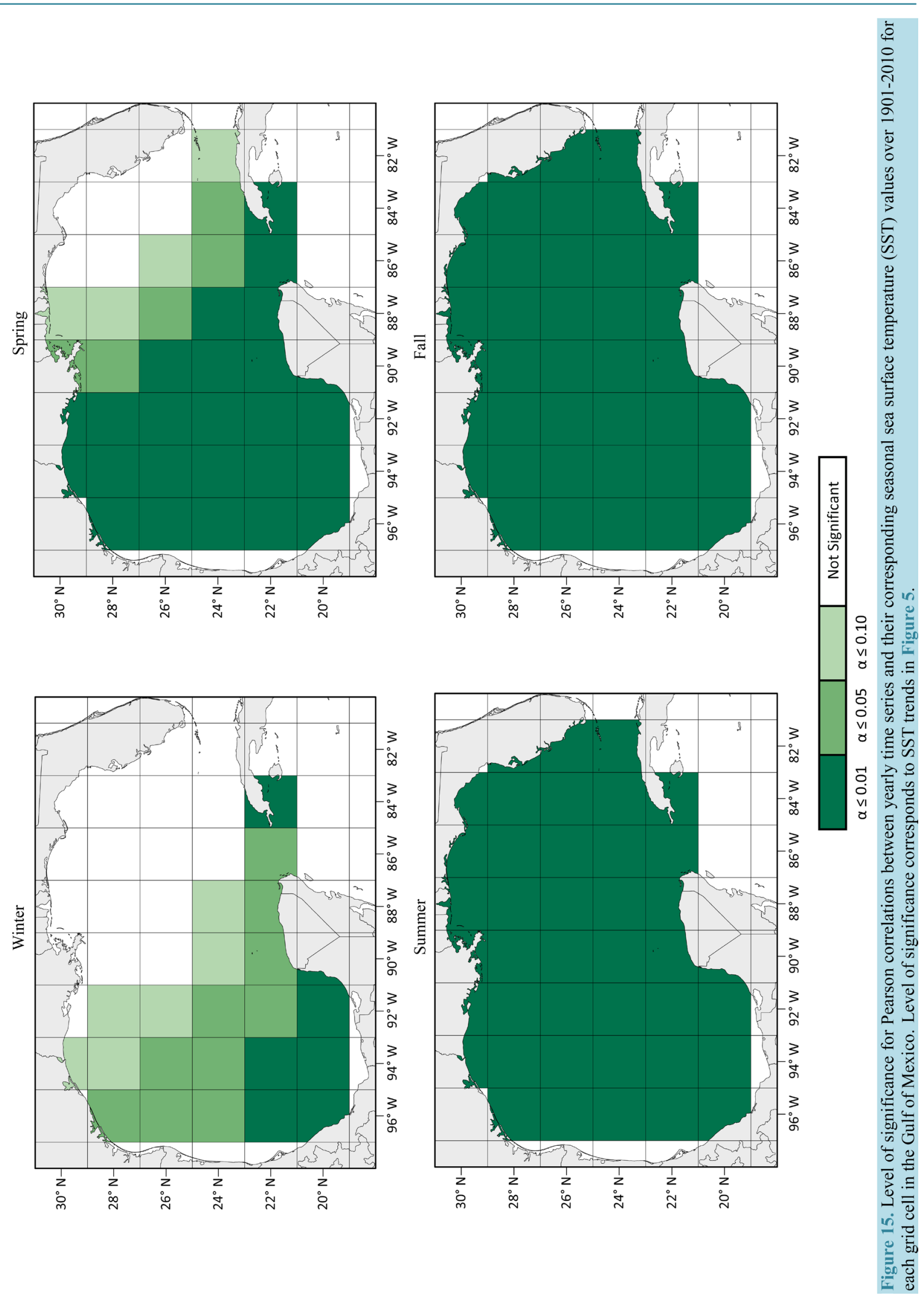


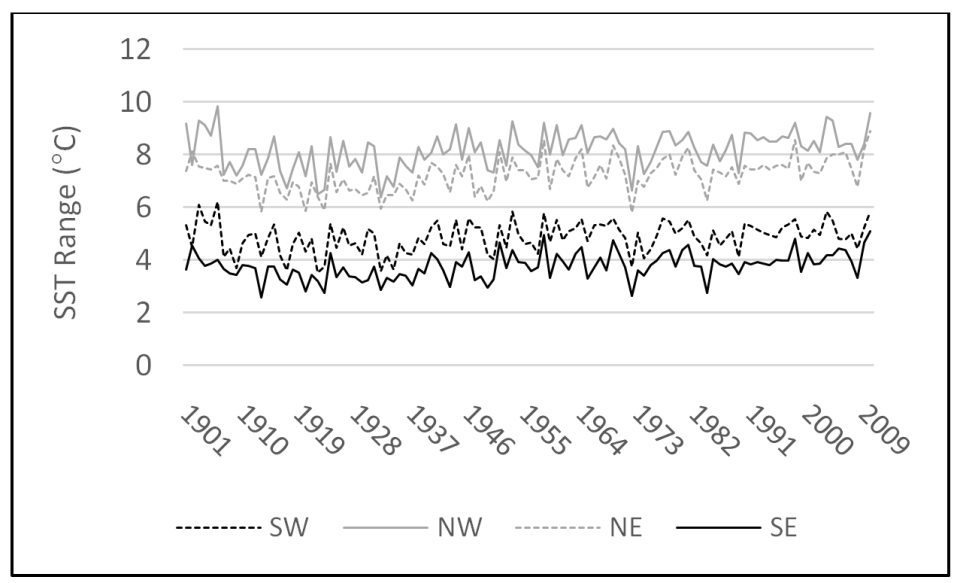

Figure 16. Seasonal SST $\left({ }^{\circ} \mathrm{C}\right)$ range for grid cells located in the southwest (SW), northwest (NW), northeast (NE), and southeast (SE) portions of the Gulf of Mexico (GoM). Locations of these grid cells within the GoM can be found in Figure 1.

examined. These cohesive shifts in SSTs over time suggest that data prior to 1950 are reliable for identifying SST changes throughout the 20th century. More importantly, it indicates that the multidecadal periodicity present in the time series had distinct seasonal differences, as well as unique spatial patterns during those seasons over the study period. For example, the areal growth and increased magnitude of cooling, or areal reduction and decreased magnitude of cooling, during winter for the northeastern portion of the GoM, is a distinctly different pattern than that of summer when there was a sharp warming gradient towards the northwestern portion of the GoM. The only spatial pattern that appeared to be consistent across the seasons was an east-west orientation: the western side of the GoM either warmed or cooled less than the eastern side, while the eastern side cooled or warmed less than the western side. Even that pattern was typically aligned more towards an intercardinal direction rather than a true east-west orientation. In addition, the magnitude of the warming tended to be greater than the magnitude of cooling, particularly in the summer. Given that global temperatures have risen over the past century, it is understandable that warming would be more dominant relative to cooling.

Overall, results of this research broadly match those of other in situ and satellite-based studies that overlap spatially and temporally with the current study. Lluch-Cota et al. [15] found a similar pattern of warming (cooling) in the western (eastern) GoM from 1910-2011. For the two locations within the GoM that Lluch-Cota et al. [15] provided time series, those time series exhibited a similar multidecadal periodicity to that found in this research. Del Monte-Luna et al. [59] found latitudinal and longitudinal SST gradients in the southwestern GoM, and again a multidecadal periodicity between 1900 and 2010. Satellite-based SST observations have shown basin-wide annual warming over more contemporary periods (i.e., since the 1980s), although the region did exhibit spatially heterogeneous trends [13] [14] [55] [63] [70]. Similar to the current findings, high rates of warming were found in the northwestern GoM and a cooling trend was observed during winter for the waters off Florida. Summer warming was also more intense, particularly towards the northwestern GoM, than any winter warming [13] [55]. Chollett et al. [13] found, however, a rapid warming in the Loop Current region of the central GoM that was not identified in the current research. While there were isolated instances when SST changes found in the current study did not exactly match those of others, the SST patterns are generally similar in the present study to those of individual studies conducted in different portions of the GoM for differing periods. An added benefit to this study is that it used a single data set with the same resolution for the entire GoM over a lengthy period, and as such is a comprehensive study that can bridge studies with varying study areas, periods, and data sources.

The east-west orientation of the spatial SST patterns (i.e., the western [eastern] side of the GoM either warmed or cooled less [cooled or warmed less] than the eastern [western] side) identified in this research and that of others may be related to Loop Current (LC hereafter). With an average extension into the GoM to about $86^{\circ} \mathrm{W}$ longitude and $24^{\circ} \mathrm{N}$ latitude [71], the LC closely aligns with the oceanographic region that delimits the east and west sides of the GoM. The anticyclonic circulation of the LC between the Yucatan Channel and the Florida Straits, however, exhibits considerable variability in its location. The LC stochastically cycles between two configurations: immature, which turns east immediately after entering the GoM, and mature, which has 
been observed to loop as far as $\sim 92^{\circ} \mathrm{W}$ longitude and $\sim 29^{\circ} \mathrm{N}$ latitude. The mature configurations usually precedes the shedding of large anticyclonic eddies, which are generated aperiodically every 3 to 21 months (averaging shedding time of $\sim 10$ - 11 months) and drift toward the west or west-northwest, and are followed by a shift to immature phases [55] [64] [72] [73]. Some research has shown that eddies shed more frequently in summer, although shedding has been observed every month of the year [52] [71] [74] [75]. As such, changes in the frequency, extent, seasonality, or magnitude of the LC and its shedding events would affect the SST temperatures in the location of the LC, but also propagate away from that region. Moreover, changes to the LC expansion and shedding process could alter its interaction with continental shelves and potentially affect coastal upwelling throughout the region, entrainment and transport of water from the Mississippi River, and transfer of heat, mass, and momentum within the GoM and between adjacent water bodies [55] [71] [76] [77].

To have contributed to the spatial and temporal SST patterns of the GoM found in the current research, however, the LC would have to possess a multidecadal periodicity. Vukovich [64] suggested that there was a change in the forcing function for the LC shedding process during the 2001-2010 period. Other studies have suggested that LC variability is modulated, at least in part, by the transport of water through the Yucatan Channel, which is linked to the meridional atmospheric pressure gradient, easterly trade winds, and westward wind stress at seasonal, interannual, and decadal time scales. These studies indicated that changes in wind stress in the eastern GoM affect the amount of water transported through the Yucatan Channel, which in turn influences LC excursions into the GoM and the frequency of LC shedding events. Moreover, the wind stress appeared to be modulated by the AMO [72] [75] [78] [79]. These series of linkages could possibly connect the LC to the multidecadal periodicity found in the GoM SST patterns, although the precise causes of eddy shedding are still poorly understood. Lluch-Cota et al. [15] visually compared the AMO with GoM SSTs and stated that the century-long (1910-2011) SST time series were strongly dominated by the AMO variability. Müller-Karger et al. [55] similarly identified a positive trend in SST anomalies between the 1980s and 2012 that was consistent with the warming phase of the AMO that commenced in the mid-1990s. However, the southeastern quadrant of their study area (i.e., the LC region) was the only quadrant that possessed a SST trend that was not significantly different $(\propto \leq 0.05)$ to that of the AMO. Del Monte-Luna et al. [59] found that long-term SST variability (i.e., 1900-2010) in the entire GoM related to the 60-year cycle of the AMO, particularly in the southwestern portion of the GoM (i.e., $r=0.6$ on the Yucatan Shelf). The study found that the northern portions of their study region were also controlled by cyclic signals with periods shorter than 10 years, and therefore, this would suggest that portions within the GoM respond differently to other large-scale, low-frequency modes of climate variability besides that of the AMO.

Other possible forcings in the GoM could involve wind-driven upwelling, meteorological forcing variability, and changes in the discharge of the Mississippi River. The possibility that wind-driven upwelling could lead to SST changes is uncertain: intensification (weakening) of alongshore winds may lead to enhanced (reduced) upwelling over portions of the world's oceans, but satellite SST data do not show long-term trends along the coast of the Yucatan Peninsula [13] [80]-[83]. Recent winter cooling trends along the coastal and shelf waters off Florida may be associated with more frequent and intense atmospheric cold fronts and southward advection of artic air-mass outbreaks that are related to the downward trend of the North Atlantic Oscillation (NAO) since the early 1990s [13] [73] [84]-[86]. More studies are needed, however, to determine if the long-term SST trends found in the current study are due to changes in the advection of cold air masses related to the NAO. It is also possible that SST shorter frequency fluctuations (i.e., $<10$ years) in the northern GoM are related to changes in the discharge of the Mississippi River, as speculated by del Monte-Luna et al. [59]. Although, it is possible that changes in the discharge rates may be in turn be related to the AMO, given the correlation between precipitation amounts for areas within the Mississippi River Basin and the AMO [72] [87]. Overall, it would appear that the multidecadal periodicity present in the GoM SSTs was related to multiple modes of climate variability, and that portions within the GoM responded differently to those modes or that there are differing factors operating within the GoM. These possibilities will be explored further in future research, which will examine relationships between temperature changes in the GoM region and modes of interannual to interdecadal variability.

\section{Summary and Conclusions}

This research assessed the spatial and temporal patterns of decadal-scale SST changes over the Gulf of Mexico for the period 1901-2010 with a gridded reconstruction of SST based on in situ data. Rhein et al. [4] and Deser 
et al. [24] noted that the lack of long-term SST measurements globally provided a serious challenge in understanding how SSTs have changed over the past century or longer. These sources also noted that global SST data have increased substantially in recent years, both in terms of spatial and temporal coverage, and adjustments have been made for known biases in the measurements, though challenges associated with their use still remain. As a result, the current study is now in a much better position to determine changes in SSTs across the Gulf of Mexico by using the Extended Reconstructed Sea Surface Temperature, version 4 (ERSST.v4), which includes in situ data that have been recently adjusted for known biases in the measurements. Moreover, this research is a comprehensive examination of the entire GoM and can bridge previous research that examined long-term SST trends in only selected portions of the GoM (e.g., [15] [59]).

The results showed that SST temperatures for the Gulf of Mexico have increased overall, closely paralleling changes in global temperatures (e.g., [47]): SSTs warmed from 1901 to 1940, followed by a period with little trend or a slight cooling until the mid-1970s, and then a subsequent warming until present. However, there was intra-basin and inter-seasonal variability found within the GoM. For example, winter showed cooling over the period 1901-2010 in the northeastern GoM along the Florida coast, while warming was found in the southwestern portion of the GoM along much of the coast of Mexico. Spring showed warming throughout the basin, with substantially higher rates found across the western half of the basin relative to the eastern half. Basin-wide warming was found in summer, especially along the northwestern quarter of the GoM offshore from Texas, Louisiana, Mississippi, and Alabama. While fall showed relatively uniform warming, there was slightly more warming in the northwestern and southeastern corners of the basin. These long-term (1901-2010) trends were statistically significant $(\propto \leq 0.01)$ for the entire GoM in summer and fall, but only significant $(\propto \leq 0.05)$ towards the southwestern portions of the GoM in winter and spring.

With few exceptions, the spatial patterns in SSTs were systematic and cohesive as the decades progressed (i.e., truncating the study period by decades): areas of warming or cooling simultaneously grew and intensified or retreated and lessened with the multidecadal periodicity previously noted. Moreover, this periodicity had distinct seasonal differences, as well as unique spatial patterns over the study period. These patterns involved gradients with latitudinal or longitudinal components, or a combination of those components: a southwest-northeast (warmer-cooler) gradient in winter, an east-west (warmer-cooler) gradient in spring and fall, and a northwest-southeast (warmer-cooler) gradient in summer. These patterns could be related to changes in the frequency, extent, seasonality, or magnitude of the LC and its shedding events, as modulated by the AMO. Other possible forcings on GoM SSTs could involve wind-driven upwelling, meteorological forcing variability, or changes in the discharge of the Mississippi River. The specific reasons for the temporal and spatial patterns for the entire GoM have yet to be completely understood. However, it is evident the processes involved differ by location in the GoM and season, and further research must include these considerations. These results have important implications regarding the physical and biological systems of the GoM, and associated impacts, as well as for studies examining climate change.

\section{References}

[1] Trenberth, K.E, Jones, P.D., Ambenje, P., Bojariu, R., Easterling, D., Klein Tank, A., Parker, D., Rahimzadeh, F., Renwick, J.A., Rusticucci, M., Soden, B. and Zhai, P. (2007) Observations: Surface and Atmospheric Climate Change. In: Solomon, S., Qin, D., Manning, M., Chen, Z., Marquis, M., Averyt, K.B., Tignor, M. and Miller, H.L., Eds., Climate Change 2007: The Physical Science Basis. Contributions of Working Group I to the Fourth Assessment Report of the Intergovernmental Panel on Climate Change, Cambridge University Press, Cambridge and New York.

[2] Roemmich, D., Gould W.J. and Gilson, J. (2012) 135 Years of Global Ocean Warming between the Challenger Expedition and the Argo Programme. Nature Climate Change, 2, 425-428. http://dx.doi.org/10.1038/nclimate1461

[3] Abraham, J.P., Baringer, M., Bindoff, N.L., Boyer, T., Cheng, L.J., Church, J.A., Conroy, J.L., Domingues, C.M., Fasullo, J.T., Gilson, J., Goni, G., Good, S.A., Gorman, J.M., Gouretski, V., Ishii, M., Johnson, G.C., Kizu, S., Lyman, J.M., Macdonald, A.M., Minkowycz, W.J., Moffitt, S.E., Palmer, M.D., Piola, A.R., Reseghetti, F., Schuckmann, K., Trenberth, K.E., Velicogna, I. and Willis, J. K. (2013) A Review of Global Ocean Temperature Observations: Implications for Ocean Heat Content Estimates and Climate Change. Reviews of Geophysics, 51, 450-483. http://dx.doi.org/10.1002/rog.20022

[4] Rhein, M., Rintoul, S.R., Aoki, S., Campos, E., Chambers, D., Feely, R.A., Gulev, S., Johnson, G.C., Josey, S.A., Kostianoy, A., Mauritzen, C., Roemmich, D., Talley, L.D. and Wang, F. (2013) Observations: Ocean. In: Stocker, T.F., Qin, D., Plattner, G.-K., Tignor, M., Allen, S.K., Boschung, J., Nauels, A., Xia, Y., Bex, V. and Midgley, P.M., Eds., Climate Change 2013: The Physical Science Basis. Contribution of Working Group I to the Fifth Assessment Report of 
the Intergovernmental Panel on Climate Change, Cambridge University Press, Cambridge and New York.

[5] Schmitt, R.W. (2008) Salinity and the Global Water Cycle. Oceanography, 21, 12-19. http://dx.doi.org/10.5670/oceanog.2008.63

[6] Church, J.A., White, N.J., Konikow, L.F., Domingues, C.M., Cogley, J.G., Rignot, E., Gregory, J.M., van den Broeke, M.R., Monaghan, A.J. and Velicogna, I. (2011) Revisiting the Earth's Sea-Level and Energy Budgets from 1961-2008. Geophysical Research Letters, 38, L18601. http://dx.doi.org/10.1029/2011gl048794

[7] Levitus, S., Antonov, J.I., Boyer, T.P., Baranova, O.K., Garcia, H.E., Locarnini, R.A., Mishonov, A.V., Reagan, J.R., Seidov, D., Yarosh, E.S. and Zweng, M.M. (2012) World Ocean Heat Content and Thermosteric Sea Level Change (0 2000 m), 1955-2010. Geophysical Research Letters, 39, L10603. http://dx.doi.org/10.1029/2012gl051106

[8] Church, J.A., White, N.J., Konikow, L.F., Domingues, C.M., Cogley, J.G., Rignot, E., Gregory, J.M., van den Broeke, M.R., Monaghan, A.J. and Velicogna, I. (2013) Correction to "Revisiting the Earth's Sea-Level and Energy Budgets from 1961 to 2008.” Geophysical Research Letters, 40, 4066. http://dx.doi.org/10.1002/grl.50752

[9] Sabine, C.L., Feely, R.A., Gruber, N., Key, R.M., Lee, K., Bullister, J.L., Wanninkhof, R., Wong, C.S., Wallace, D.W.R., Tilbrook, B., Millero, F.J., Peng, T.-H., Kozyr, A., Ono T. and Rios, A.F. (2004) The Oceanic Sink for Anthropogenic $\mathrm{CO}_{2}$. Science, 305, 367-371. http://dx.doi.org/10.1126/science.1097403

[10] Le Quéré, C., Takahashi, T., Buitenhuis, E.T., Rödenbeck, C. and Sutherland, S.C. (2010) Impact of Climate Change and Variability on the Global Oceanic Sink of $\mathrm{CO}_{2}$. Global Biogeochemical Cycles, 24, GB4007. http://dx.doi.org/10.1029/2009gb003599

[11] Le Quéré, C., Andres, R.J., Boden, T., Conway, T., Houghton, R.A., House, J.I., Marland, G., Peters, G.P., van der Werf, G.R., Ahlström, A., Andrew, R.M., Bopp, L., Canadell, J.G., Ciais, P., Doney, S.C., Enright, C., Friedlingstein, P., Huntingford, C., Jain, A.K., Jourdain, C., Kato, E., Keeling, R.F., Klein Goldewijk, K., Levis, S., Levy, P., Lomas, M., Poulter, B., Raupach, M.R., Schwinger, J., Sitch, S., Stocker, B.D., Viovy, N., Zaehle, S. and Zeng, N. (2013) The Global Carbon Budget 1959-2011. Earth System Science Data, 5, 165-185. http://dx.doi.org/10.5194/essd-5-165-2013

[12] Burrows, M.T., Schoeman, D.S., Buckley, L.B., Moore, P., Poloczanska, E.S., Brander, K.M., Brown, C., Bruno, J.F., Duarte, C.M., Halpern, B.S., Holding, J., Kappel, C.V., Kiessling, W., O’Connor, M.I., Pandolfi, J.M., Parmesan, C., Schwing, F.B., Sydeman, W.J. and Richardson, A.J. (2011) The Pace of Shifting Climate in Marine and Terrestrial Ecosystems. Science, 334, 652-655. http://dx.doi.org/10.1126/science.1210288

[13] Chollett, I., Müller-Karger, F.E., Heron, S.F., Skirving, W. and Mumby, P.J. (2012) Seasonal and Spatial Heterogeneity of Recent Sea Surface Temperature Trends in the Caribbean Sea and Southeast Gulf of Mexico. Marine Pollution Bulletin, 64, 956-965. http://dx.doi.org/10.1016/j.marpolbul.2012.02.016

[14] Lima, F.P. and Wethey, D.S. (2012) Three Decades of High-Resolution Coastal Sea Surface Temperatures Reveal more than Warming. Nature Communications, 3, 1-13. http://dx.doi.org/10.1038/ncomms1713

[15] Lluch-Cota, S.E., Tripp-Valdez, M., Lluch-Cota, D.B., Lluch-Belda, D., Verbesselt, J., Herrera-Cervantes, H. and Bautista-Romero, J.J. (2013) Recent Trends in Sea Surface Temperature off Mexico. Atmósfera, 26, 537-546. http://dx.doi.org/10.1016/S0187-6236(13)71094-4

[16] Nye, J.A., Baker, M.R., Bell, R., Kenny, A., Kilbourne, K.H., Friedland, K.D., Martino, E., Stachura, M.M., Van Houtan, K.S. and Wood, R. (2014) Ecosystem Effects of the Atlantic Multidecadal Oscillation. Journal of Marine Systems, 133, 103-116. http://dx.doi.org/10.1016/j.jmarsys.2013.02.006

[17] Cione, J.J. and Uhlhorn, E.W. (2003) Sea Surface Temperature Variability in Hurricanes: Implications with Respect to Intensity Change. Monthly Weather Review, 131, 1783-1796. http://dx.doi.org/10.1175//2562.1

[18] Saunders, M.A. and Lea, A.S. (2008) Large Contributions of Sea Surface Warming to Recent Increase in Atlantic Hurricane Activity. Nature, 451, 557-561. http://dx.doi.org/10.1038/nature06422

[19] Kilic, C. and Raible, C.C. (2013) Investigating the Sensitivity of Hurricane Intensity and Trajectory to Sea Surface Temperatures Using the Regional Model WRF. Meteorologische Zeitschrift, 22, 685-698. http://dx.doi.org/10.1127/0941-2948/2013/0472

[20] Ting, M., Kushnir, Y., Seager, R. and Li, C. (2009) Forced and Internal Twentieth-Century SST Trends in the North Atlantic. Journal of Climate, 22, 1469-1481. http://dx.doi.org/10.1175/2008JCLI2561.1

[21] Hartmann, D.L., Klein Tank, A.M.G., Rusticucci, M., Alexander, L.V., Brönnimann, S., Charabi, Y., Dentener, F.J., Dlugokencky, E.J., Easterling, D.R., Kaplan, A., Soden, B.J., Thorne, P.W., Wild M. and Zhai, P.M. (2013) Observations: Atmosphere and Surface. In: Stocker, T.F., Qin, D., Plattner, G.-K., Tignor, M., Allen, S.K., Boschung, J., Nauels, A., Xia, Y., Bex V. and Midgley, P.M., Eds., Climate Change 2013: The Physical Science Basis. Contribution of Working Group I to the Fifth Assessment Report of the Intergovernmental Panel on Climate Change, Cambridge University Press, Cambridge and New York.

[22] Matthews, J.B.R. (2013) Comparing Historical and Modern Methods of Sea Surface Temperature Measurement-Part 1: Review of Methods, Field Comparisons and Dataset Adjustments. Ocean Science, 9, 683-694. 
http://dx.doi.org/10.5194/os-9-683-2013

[23] Huang, B., Banzon, V.F., Freeman, E., Lawrimore, J., Liu, W., Peterson, T.C., Smith, T.M., Thorne, P.W., Woodruff, S.D. and Zhang, H.-M. (2015) Extended Reconstructed Sea Surface Temperature Version 4 (ERSST.v4). Part I: Upgrades and Intercomparisons. Journal of Climate, 28, 911-930. http://dx.doi.org/10.1175/JCLI-D-14-00006.1

[24] Deser, C., Phillips, A.S. and Alexander, M.A. (2010) Twentieth Century Tropical Sea Surface Temperature Trends Revisited. Geophysical Research Letters, 37, L10701. http://dx.doi.org/10.1029/2010gl043321

[25] Kennedy, J.J., Smith, R.O. and Rayner, N.A. (2012) Using AATSR Data to Assess the Quality of In Situ Sea-Surface Temperature Observations for Climate Studies. Remote Sensing of Environment, 116, 79-92. http://dx.doi.org/10.1016/j.rse.2010.11.021

[26] Yasunaka, S. and Hanawa, K., (2011) Intercomparison of Historical Sea Surface Temperature Datasets. International Journal of Climatology, 31, 1056-1073. http://dx.doi.org/10.1002/joc.2104

[27] Liu, W., Huang, B., Thorne, P.W., Banzon, V.F., Zhang, H.-M., Freemand, E., Lawrimore, J., Peterson, T.C., Smith, T.M. and Woodruff, S.D. (2015) Extended Reconstructed Sea Surface Temperature Version 4 (ERSST.v4): Part II. Parametric and Structural Uncertainty Estimates. Journal of Climate, 28, 931-951. http://dx.doi.org/10.1175/JCLI-D-14-00007.1

[28] Folland, C.K. and Parker, D.E. (1995) Correlation of Instrumental Biases in Historical Sea Surface Temperature Data. Quarterly Journal of the Royal Meteorological Society, 121, 319-367. http://dx.doi.org/10.1002/qi.49712152206

[29] Kent, E.C. and Taylor, P.K. (2006) Towards Estimating Climatic Trends in SST. Part I: Methods and Measurement. Journal of Atmospheric and Oceanic Technology, 23, 464-475. http://dx.doi.org/10.1175/JTECH1843.1

[30] Kent, E.C., Kennedy, J.J., Berry, D.I. and Smith, R.O. (2010) Effects of Instrumentation Changes on Sea Surface Temperature Measured In Situ. Wiley Interdisciplinary Reviews: Climate Change, 1, 718-728. http://dx.doi.org/10.1002/wcc.55

[31] Kennedy, J.J. (2014) A Review of Uncertainty in In Situ Measurements and Data Sets of Sea Surface Temperature. Reviews in Geophysics, 52, 1-32. http://dx.doi.org/10.1002/2013RG000434

[32] Kennedy, J.J., Raynor, N.A., Smith, R.O., Parker, D.E. and Saunby, M. (2011) Reassessing Biases and Other Uncertainties in Sea-Surface Temperature Observations Measured In Situ since 1850, Part 1: Measurement and Sampling Uncertainties. Journal of Geophysical Research, 116, D14103.

[33] Legler, D.M., Freeland, J.J., Lumpkin, R., Ball, G., McPhaden, M.J., North, S., Crowley, R., Goni, G.J., Send, U. and Merrifield, M.A. (2015) The Current Status of the Real-Time In Situ Global Ocean Observing System for Operational Oceanography. Journal of Operational Oceanography, 8, 189-200. http://dx.doi.org/10.1080/1755876X.2015.1049883

[34] Reynolds, R.W., Rayner, N.A., Smith, T.M., Stokes, D.C. and Wang, W. (2002) An Improved In Situ and Satellite SST Analysis for Climate. Journal of Climate, 15, 1609-1625. http://dx.doi.org/10.1175/1520-0442(2002)015<1609:AIISAS>2.0.CO;2

[35] Ravichandran, M. (2011) In-Situ Observing Systems. In: Schiller, A. and Brassington, G.B., Eds., Operational Oceanography in the 21st Century, Springer, Dordtrecht, 55-90.

[36] Thompson, D.W.J., Kennedy, J.J., Wallace, J.M. and Jones, P.D. (2008) A Large Discontinuity in the Mid-Twentieth Century in Observed Global-Mean Surface Temperature. Nature, 453, 646-649. http://dx.doi.org/10.1038/nature06982

[37] Kennedy, J.J., Raynor, N.A., Smith, R.O., Parker, D.E. and Saunby, M. (2011b) Reassessing Biases and Other Uncertainties in Sea-Surface Temperature Observations Measured In Situ since 1850, Part 2: Biases and Homogenisation. Journal of Geophysical Research, 116, D14104.

[38] Jones, P.D. and Wigley, T.M.L. (2010) Estimation of Global Temperature Trends: What's Important and What Isn’t. Climatic Change, 100, 59-69. http://dx.doi.org/10.1007/s10584-010-9836-3

[39] Karl, T.R., Arguez, A., Huang, B., Lawrimore, J.H., McMahon, J.R., Menne, M.J., Peterson, T.C., Vose, R.S. and Zhang, H.-M. (2015) Possible Artifacts of Data Biases in the Recent Global Surface Warming Hiatus. Science, 348, 1469-1472. http://dx.doi.org/10.1126/science.aaa5632

[40] Gouretski, V., Kennedy, J., Boyer, T. and Köhl, A. (2012) Consistent Near-Surface Ocean Warming since 1900 in Two Largely Independent Observing Networks. Geophysical Research Letters, 39, L19606. http://dx.doi.org/10.1029/2012gl052975

[41] Kaplan, A., Cane, M.A., Kushnir, Y., Clement, A.C., Blumenthal, M.B. and Rajagopalan, B. (1998) Analyses of Global Sea Surface Temperature 1856-1991. Journal of Geophysical Research, 103, 18567-18589. http://dx.doi.org/10.1029/97JC01736

[42] Kaplan, A., Cane, M.A. and Kushnir, Y. (2003) Reduced Space Approach to the Optimal Analysis of Historical Marine Observations. Accomplishments, Difficulties, and Prospects. In: Advances in the Applications of Marine Climatology. The Dynamic Part of the WMO Guide to the Applications of Marine Meteorology, World Meteorological Organization, 
Geneva, 199-216.

[43] Rayner, N.A., Parker, D.E., Horton, E.B., Folland, C.K., Alexander, L.V., Rowell, D.P., Kent, E.C. and Kaplan, A. (2003) Global Analyses of Sea Surface Temperature, Sea Ice, and Night Marine Air Temperature since the Late Nineteenth Century. Journal of Geophysical Research, 108, 4407. http://dx.doi.org/10.1029/2002JD002670

[44] Hirahara, S., Ishii, M. and Fukuda, Y. (2014) Centennial-Scale Sea Surface Temperature Analysis and Its Uncertainty. Journal of Climate, 27, 57-75. http://dx.doi.org/10.1175/JCLI-D-12-00837.1

[45] Solomon, A. and Newman, M. (2012) Reconciling Disparate 20th Century Indo-Pacific Ocean Temperature Trends in the Instrumental Record. Nature Climate Change, 2, 691-699. http://dx.doi.org/10.1038/nclimate1591

[46] Bindoff, N.L., Stott, P.A., Achuta Rao, K.M., Allen, M.R., Gillett, N., Gutzler, D., Hansingo, K., Hegerl, G., Hu, Y., Jain, S., Mokhov, I.I., Overland, J., Perlwitz, J., Sebbari R. and Zhang, X. (2013) Detection and Attribution of Climate Change: From Global to Regional. In: Stocker, T.F., Qin, D., Plattner, G.-K., Tignor, M., Allen, S.K., Boschung, J., Nauels, A., Xia, Y., Bex V. and Midgley, P.M., Eds., Climate Change 2013: The Physical Science Basis. Contribution of Working Group I to the Fifth Assessment Report of the Intergovernmental Panel on Climate Change, Cambridge University Press, Cambridge and New York.

[47] Hansen, J., Ruedy, R., Sato, M. and Lo, K. (2010) Global Surface Temperature Change. Reviews of Geophysics, 48, RG 4004. http://dx.doi.org/10.1029/2010rg000345

[48] Hewitson, B., Janetos, A.C., Carter, T.R., Giorgi, F., Jones, R.G., Kwon, W.-T., Mearns, L.O., Schipper, E.L.F. and van Aalst, M. (2014) Regional Context. In: Barros, V.R., Field, C.B., Dokken, D.J., Mastrandrea, M.D., Mach, K.J., Bilir, T.E., Chatterjee, M., Ebi, K.L., Estrada, Y.O., Genova, R.C., Girma, B., Kissel, E.S., Levy, A.N., MacCracken, S., Mastrandrea, P.R. and White, L.L., Eds., Climate Change 2014: Impacts, Adaptation, and Vulnerability. Part B: Regional Aspects. Contributions of Working Group II to the Fifth Assessment Report of the Intergovernmental Panel on Climate Change, Cambridge University Press, Cambridge and New York, 1439-1498.

[49] Romero-Lankao, P., Smith, J.B., Davidson, D.J., Diffenbaugh, N.S., Kinney, P.L., Kirshen, R., Kovacs, P. and Villers Ruiz, L. (2014) North American. In: Barros, V.R., Field, C.B., Dokken, D.J., Mastrandrea, M.D., Mach, K.J., Bilir, T.E., Chatterjee, M., Ebi, K.L., Estrada, Y.O., Genova, R.C., Girma, B., Kissel, E.S., Levy, A.N., MacCracken, S., Mastrandrea, P.R. and White, L.L., Eds., Climate Change 2014: Impacts, Adaptation, and Vulnerability. Part B: Regional Aspects. Contributions of Working Group II to the Fifth Assessment Report of the Intergovernmental Panel on Climate Change, Cambridge University Press, Cambridge and New York, 1439-1498.

[50] Adams, C.M., Herandez, E. and Cato, J.C. (2004) The Economic Significance of the Gulf of Mexico Related to Population, Income, Employment, Minerals, Fisheries and Shipping. Ocean \& Coastal Management, 47, 565-580. http://dx.doi.org/10.1016/j.ocecoaman.2004.12.002

[51] Poore, R.Z., De Long, K.L., Richey, J.N. and Quinn, T.M. (2009) Evidence of Multidecadal Climate Variability and the Atlantic Decadal Oscillation from a Gulf of Mexico Sea-Surface Temperature-Proxy Record. Geo-Marine Letters, 29, 477-484. http://dx.doi.org/10.1007/s00367-009-0154-6

[52] Alvera-Azcárate, A., Barth, A. and Weisberg, R.H. (2009) The Surface Circulation of the Caribbean Sea and Gulf of Mexico as Inferred from Satellite Altimetry. Journal of Physical Oceanography, 39, 640-657. http://dx.doi.org/10.1175/2008JPO3765.1

[53] Zavala-Hidalgo, J., Parés-Sierra, A. and Ochoa, J. (2002) Seasonal Variability of the Temperature and Heat Fluxes in the Gulf of Mexico. Atmósfera, 15, 81-104.

[54] De Long, K.L., Flannery, J.A., Poore, R.Z., Quinn, T.M., Maupin, C.R., Lin, K. and Shen, C.-C. (2014) A Reconstruction of Sea Surface Temperature Variability in the Southeastern Gulf of Mexico from 1734 to 2008 C.E. Using CrossDated Sr/Ca Records from the Coral Siderastrea Sidereal. Paleooceanography, 29, 1-20. http://dx.doi.org/10.1002/2013PA002524

[55] Müller-Karger, F.E., Smith, J.P., Werner, S., Chen, R., Roffer, M., Liu, Y., Muhling, B., Lindo-Atichati, D., Lamkin, J., Cergeira-Estrada, S. and Enfield, D.B. (2015) Natural Variability of Surface Oceanographic Conditions in the Offshore Gulf of Mexico. Progress in Oceanography, 134, 54-76. http://dx.doi.org/10.1016/j.pocean.2014.12.007

[56] Trenberth, K.E. and Shea, D.J. (2006) Atlantic Hurricanes and Natural Variability in 2005. Geophysical Research Letters, 33, L12704. http://dx.doi.org/10.1029/2006gl026894

[57] Goldenberg, S.B., Landsea, C.W., Mestas-Nuñez, A.M. and Gray, W.M. (2001) The Recent Increase in Atlantic Hurricane Activity: Causes and Implications. Science, 293, 474-479. http://dx.doi.org/10.1126/science.1060040

[58] Karnauskas, M., Schirripa, M.J., Kelble, C.R., Cook, R.S. and Crait, J.K. (2013) Ecosystem Status Report for the Gulf of Mexico. NOAA Technical Memorandum NMFS-SEFSC-653.

[59] del Monte-Luna, P., Villalobos, H. and Arreguín-Sánchez, F. (2015) Variability of Sea Surface Temperature in the Southwestern Gulf of Mexico. Continental Shelf Research, 102, 73-79. http://dx.doi.org/10.1016/j.csr.2015.04.017

[60] Richey, J.N., Poore, R.Z., Flower, B.P. and Quinn, T.M. (2007) 1400 yr Multiproxy Record of Climate Variability 
from the Northern Gulf of Mexico. Geology, 35, 423-426. http://dx.doi.org/10.1130/G23507A.1

[61] Kilbourne, K.H., Quinn, T.M., Webb, R., Guilderson, T., Nyberg, J. and Winter, A. (2008) Paleoclimate Proxy Perspective on Caribbean Climate since the Year 1751: Evidence of Cooler Temperatures and Multidecadal Variability. Paleooceanography, 23, PA3220.

[62] Winter, A., Miller, T., Kushnir, Y., Sinha, A., Timmermann, A., Jury, M.R., Gallup, C., Cheng, H. and Edwards, R.L. (2010) Evidence for 800 Years of North Atlantic Multi-Decadal Variability from a Puerto Rican Speleothem. Earth and Planetary Science Letters, 308, 23-28. http://dx.doi.org/10.1016/j.epsl.2011.05.028

[63] Good, S.A., Corlett, G.K., Remedios, J.J., Noyes, E.J. and Llewellyn-Jones, D.T. (2007) The Global Trend in Sea Surface Temperature from 20 Years of Advanced Very High Resolution Radiometer Data. Journal of Climate, 20, 12551264. http://dx.doi.org/10.1175/JCLI4049.1

[64] Vukovich, F.M. (2012) Changes in the Loop Current's Eddy Shedding in the Period 2001-2010. International Journal of Oceanography, 2012, 1-18. http://dx.doi.org/10.1155/2012/439042

[65] Large, W.G. and Yeager, S.G. (2012) On the Observed Trends and Changes in Global Sea Surface Temperature and Air-Sea Heat Fluxes (1984-2006). Journal of Climate, 25, 6123-6135. http://dx.doi.org/10.1175/JCLI-D-11-00148.1

[66] Rayner, N.A., Brohan, P., Parker, D.E., Folland, C.K., Kennedy, J.J., Vanicek, M., Ansell, T.J. and Tett, S.F.B. (2006) Improved Analyses of Changes and Uncertainties in Sea Surface Temperature Measured In Situ since the Mid-Nineteenth Century: The HadSST2 Dataset. Journal of Climate, 19, 446-469. http://dx.doi.org/10.1175/JCLI3637.1

[67] Woodruff, S.D., Worley, S.J., Lubker, S.J., Ji, A., Freeman, J.E., Berry, D.I., Brohan, P., Kent, E.C., Reynolds, R.W., Smith, S.R. and Wilkinson, C. (2011) ICOADS Release 2.5: Extensions and Enhancements to the Surface Marine Meteorological Archive. International Journal of Climatology, 31, 951-967. http://dx.doi.org/10.1002/joc.2103

[68] Liu, Y., Weisberg, R.H. and He, R. (2006) Sea Surface Temperature Patterns on the West Florida Shelf Using Growing Hierarchical Self-Organizing Maps. Journal of Atmospheric and Oceanic Technolology, 23, 325-338. http://dx.doi.org/10.1175/JTECH1848.1

[69] Callejas-Jimenez, M., Santamaria-del-Angel, E., Gonzalez-Silvera, A., Millan-Nuñez, R. and Cajal-Medrano, R. (2012) Dynamic Regionalization of the Gulf of Mexico Based on Normalized Radiances (nLw) Derived from MODIS-Aqua. Continental Shelf Research, 37, 8-14. http://dx.doi.org/10.1016/j.csr.2012.01.014

[70] Muhling, B.A., Lamkin, J.T. and Richards, W.J. (2012) Decadal-Scale Responses of Larval Assemblages to Multiple Ecosystem Processes in the Northern Gulf of Mexico. Marine Ecology Progress Series, 450, 37-53. http://dx.doi.org/10.3354/meps09540

[71] Vukovich, F.M. (2007) Climatology of Ocean Features in the Gulf of Mexico Using Satellite Remote Sensing Data. Journal of Physical Oceanography, 37, 689-707. http://dx.doi.org/10.1175/JPO2989.1

[72] Nürnberg, D., Ziegler, M., Karas, C., Tiedemann, R. and Schmidt, M.W. (2008) Interacting Loop Current Variability and Mississippi River Discharge over the Past 400 kyr. Earth and Planetary Science Letters, 272, 278-289. http://dx.doi.org/10.1016/j.epsl.2008.04.051

[73] Rudzin, J.E., Morey, S.L. and Bourassa, M.A. (2013) The Influence of the Loop Current Position on Winter Sea Surface Temperatures in the Florida Straits. Earth Interactions, 17, 1-9. http://dx.doi.org/10.1175/2013EI000521.1

[74] Chang, Y.-L. and Oey, L.-Y. (2012) Why Does the Loop Current Tend to Shed More Eddies in Summer and Winter? Geophysical Research Letters, 39, L05605. http://dx.doi.org/10.1029/2011GL050773

[75] Lindo-Atichati, D. and Sangrà, S. (2015) Observational Evidence for Atmospheric Modulation of the Loop Current Migrations. Frontiers in Earth Science, 9, 683-690. http://dx.doi.org/10.1007/s11707-015-0537-0

[76] Weisberg, R.H., He, R., Kilpatrick, G., Müller-Karger, F. and Walsh, J.J. (2004) Coastal Ocean Circulation Influences on Remotely Sensed Optical Properties: A West Florida Shelf Case Study. Oceanography, 17, 68-75. http://dx.doi.org/10.5670/oceanog.2004.49

[77] Hu, C., Nelson, J.R., Johns, E., Chen, Z., Weisberg, R.H. and Müller-Karger, F.E. (2005) Mississippi River Water in the Florida Straits and in the Gulf Stream off Georgia in Summer 2004. Geophysical Research Letters, 32, L14606. http://dx.doi.org/10.1029/2005gl022942

[78] Chang, Y.-L. and Oey, L.-Y. (2013) Coupled Response of the Trade Wind, SST Gradient, and SST in the Caribbean Sea, and the Potential Impact on Loop Current's Interannual Variability. Journal of Physical Oceanography, 43, 13251344. http://dx.doi.org/10.1175/JPO-D-12-0183.1

[79] Chang, Y.-L. and Oey, L.-Y. (2013) Loop Current Growth and Eddy Shedding Using Models and Observations: Numerical Process Experiments and Satellite Altimetry Data. Journal of Physical Oceanography, 43, 669-689. http://dx.doi.org/10.1175/JPO-D-12-0139.1

[80] Merino, M. (1997) Upwelling on the Yucatan Shelf: Hydrographic Evidence. Journal of Marine Systems, 13, $101-121$. http://dx.doi.org/10.1016/S0924-7963(96)00123-6 
[81] Demarcq, H. (2009) Trends in Primary Production, Sea Surface Temperature and Wind in Upwelling Systems (19982007). Progress in Oceanography, 83, 376-385. http://dx.doi.org/10.1016/j.pocean.2009.07.022

[82] Bakun, A., Field, D.B., Redondo-Rodriguez, A.N.A. and Weeks, S.J. (2010) Greenhouse Gas, Upwelling-Favorable Winds, and the Future of Coastal Ocean Upwelling Ecosystems. Global Change Biology, 16, 1213-1228. http://dx.doi.org/10.1111/j.1365-2486.2009.02094.X

[83] Pérez, F.F., Padín, X.A., Pazos, Y., Gilcoto, M., Cabanas, M., Pardo, P.C., Doval, M.D. and Farina-Busto, L. (2010) Plankton Response to Weakening of the Iberian Coastal Upwelling. Global Change Biology, 16, 1258-1267. http://dx.doi.org/10.1111/j.1365-2486.2009.02125.x

[84] Melo-González, N.M., Müller-Karger, F.E., Cerdeira-Estrada, S., Pérez de los Reyes, R., Victoria del Río, I., Cárdenas-Pérez, P. and Mitrani-Arenal, I. (2000) Near-Surface Phytoplankton Distribution in the Western Intra-Americas Sea: The Influence of El Niño and Weather Events. Journal of Geophysical Research (C Oceans), 105, 14029-14043. http://dx.doi.org/10.1029/2000JC900017

[85] Wang, C., Liu, H. and Lee, S.-K. (2010) The Record-Breaking Cold Temperatures during the Winter of 2009/2010 in the Northern Hemisphere. Atmospheric Science Letters, 11, 161-168. http://dx.doi.org/10.1002/asl.278

[86] Kemp, D.W., Oakley, C.A., Thornhill, D.J., Newcomb, L.A., Schmidt, G.W. and Fitt, W.K. (2011) Catastrophic Mortality on Inshore Coral Reefs of the Florida Keys Due to Severe Low-Temperature Stress. Global Change Biology, 17, 3468-3477. http://dx.doi.org/10.1111/j.1365-2486.2011.02487.x

[87] Enfield, D.B., Mestas-Nuñez, A.M. and Trimble, P.J. (2001) The Atlantic Multidecadal Oscillation and Its Relation to Rainfall and River Flows in the Continental U.S. Geophysical Research Letters, 28, 2077-2080. http://dx.doi.org/10.1029/2000GL012745 